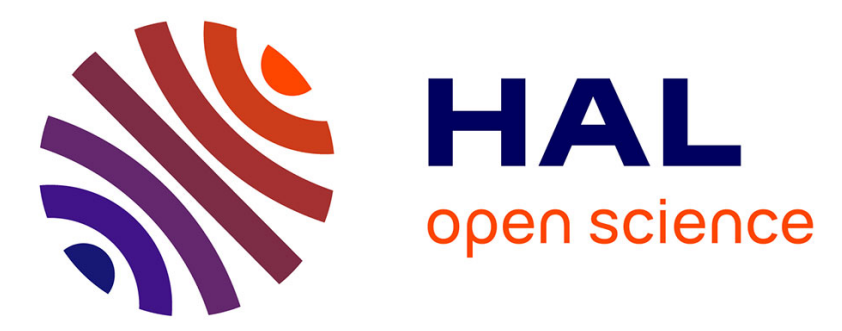

\title{
Tumor cell/endothelial cell tight contact upregulates endothelial adhesion molecule expression mediated by NFkappaB: differential role of the shear stress.
}

Oualid Haddad, Roxana Chotard-Ghodsnia, Claude Verdier, Alain Duperray

\section{- To cite this version:}

Oualid Haddad, Roxana Chotard-Ghodsnia, Claude Verdier, Alain Duperray. Tumor cell/endothelial cell tight contact upregulates endothelial adhesion molecule expression mediated by NFkappaB: differential role of the shear stress.. Experimental Cell Research, 2010, 316 (4), pp.615-626. 10.1016/j.yexcr.2009.11.015 . inserm-00437626

\section{HAL Id: inserm-00437626 https://www.hal.inserm.fr/inserm-00437626}

Submitted on 1 Dec 2009

HAL is a multi-disciplinary open access archive for the deposit and dissemination of scientific research documents, whether they are published or not. The documents may come from teaching and research institutions in France or abroad, or from public or private research centers.
L'archive ouverte pluridisciplinaire HAL, est destinée au dépôt et à la diffusion de documents scientifiques de niveau recherche, publiés ou non, émanant des établissements d'enseignement et de recherche français ou étrangers, des laboratoires publics ou privés. 
Regular article

\section{Tumor cell/endothelial cell tight contact upregulates endothelial}

adhesion molecule expression mediated by NFKB: differential role

\section{of the shear stress}

Oualid Haddad $^{1,2^{*}}$, Roxana Chotard-Ghodsnia ${ }^{3,4,5}$, Claude Verdier $^{2,6}$, Alain Duperray ${ }^{1,2}$

${ }^{1}$ INSERM U823, Grenoble, France,

${ }^{2}$ Université Joseph Fourier - Grenoble I, France,

${ }^{3}$ Université de Limoges, France,

${ }^{4}$ CNRS, Laboratoire SPCTS (UMR 6638), France,

${ }^{5}$ ENSCI, 43-73 Avenue Albert Thomas, 87065 Limoges Cedex, France,

${ }^{6}$ CNRS, Laboratoire de Spectrométrie Physique (UMR 5588), 38402 Saint Martin d'Hères, France.

Word count (introduction through references): 6525

* Corresponding author: Institut Albert Bonniot - Centre de Recherche INSERM 823

Equipe 8-BP 170

38042 Grenoble Cedex 9 - FRANCE

Mail : oualid_haddad@yahoo.fr

Phone : (33).4.76.54.94.52

Fax : (33).4.76.54.94.13 


\begin{abstract}
Cancer metastasis is a multistep process involving cell-cell interactions, but little is known about the adhesive interactions and signaling events during extravasation of tumor cells (TCs). In this study, cell adhesion molecule (CAM) expression was investigated using an in vitro assay, in which TCs were seeded onto an endothelial cell (ECs) monolayer and cocultured during 5 hours. Flow cytometry, confocal microscopy as well as western blot analysis indicated that endothelial ICAM-1 (Inter Cellular Adhesion Molecule-1), VCAM-1 (Vascular Adhesion Molecule-1) and E-selectin were up-regulated after TC-EC coculture, whereas no change was observed for CAMs expression in tumor cells. This increased CAMs expression required tight contact between TCs and ECs. Incubation of ECs with the pyrrolidine-dithiocarbamate $\mathrm{NF \kappa B}$ inhibitor prior to coculture, fully prevented cocultureinduced expression of endothelial CAMs. Using specific blocking antibodies we showed an implication of ICAM-1 and VCAM-1 for TCs extravasation and VCAM-1 for adhesion. Moreover, fluid flow experiments revealed that high shear stress totally abolished cocultureinduced as well as TNF $\alpha$-induced CAMs over-expression. This study suggests that TCs could act as a potent inflammatory stimulus on ECs by inducing CAMs expression via NFkB activation, and that this action can be modulated by shear stress.
\end{abstract}

Keywords: metastasis, NFאB, endothelium, flow, cancer, adhesion molecule, interaction 


\section{Introduction:}

Hematogenous cancer metastasis is a complex multistep process that involves the detachment of TCs from the primary tumor, migration through tumor-derived vessels into blood stream, survival in blood circulation, extravasation (migration through vascular endothelium to target organs), and finally establishment of secondary tumors [1]. All these steps involve close interactions between Tumor Cells (TCs) and Endothelial Cells (ECs) which can be mediated by soluble factors as well as Cell Adhesion Molecules (CAMs). The progression of tumor malignancies is often associated with changes in CAMs profile [2], indicating that CAMs play an important role in cancer metastasis. To date, little is known about the details of tumor metastasis and the precise molecular mechanisms involved when TCs interact with the EC layer.

The process of leukocyte diapedesis can serve as a model for describing the interactions between circulating TCs and ECs [3]. This process occurs in several major steps: leukocytes rolling on the endothelial surface in the direction of blood flow, cell activation, adhesion, locomotion to and protrusions extension through interendothelial junctions, and finally transendothelial migration [4]. ECs provide an interface between blood and the vessel wall, and are constantly subjected to hemodynamic forces. It is well established that leukocyte interactions with ECs as well as leukocyte extravasation into inflamed tissues are affected by flow [5]. Similarly to leukocytes, TC rolling before arrest on the endothelial surface has already been observed under in vitro flow conditions [6]. However other studies have shown that initial arrest of TCs occurs primarily by size restriction in capillaries [7] without cell rolling on the endothelium [8]. In some case, TC adhesion to the endothelium can be leukocytes dependent. Strell et al. showed that neutrophil granulocytes mediate the adhesion of breast cells to the endothelium in flow condition [9], and that. the immunoglobulin ICAM1 (Inter Cellular Adhesion Molecule-1) and its beta2-integrin ligand are likely implicated. 
Shear stress is known to induce ECs alignment and elongation [10], cytoskeleton rearrangement [11] and modification of gene expression [12-14] with activation of the Nuclear Factor Kappa B (NFאB) signaling pathway [15].

$\mathrm{NF} \kappa \mathrm{B}$ is a dimeric transcription factor formed by members of a family of proteins, mediating its functional effects through the transcriptional regulation of $\mathrm{NF \kappa B}$ target genes. In most cells, NFkB complexes are inactive, residing primarily in the cytoplasm complexed with one member of the family of inhibitory $\kappa \mathrm{B}(\mathrm{I} \kappa \mathrm{B})$ proteins such as $\mathrm{I} \kappa \mathrm{B} \alpha$ and $\mathrm{I} \kappa \mathrm{B} \beta$. Upon

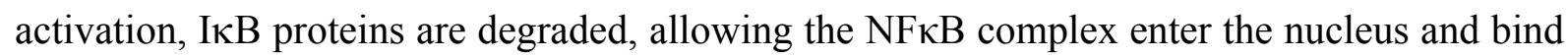
to specific sequences located in the promoter region of target genes to modulate their expression [16]. Numerous genes are regulated by NFkB, e.g. chemokines MCP-1 and IL-8 [17], cytokines TNF $\alpha$ and IFN- $\gamma$ [18], and adhesion molecules ICAM-1 [19], VCAM-1 [20, 21] and E-selectin [22].

We previously characterized T24 cell line (Human bladder carcinoma) spreading on an EC monolayer and we demonstrated that shear stress levels modulate TCs spreading patterns [23]. The purpose of the present study is to further investigate the effect of T24 cells-EC contact on CAMs expression, as well as to characterize the influence of shear stress levels on ECs response. 


\section{Materials and methods}

\section{Cell lines and reagents}

Human umbilical vein endothelial cells (HUVECs) were isolated by collagenase digestion of umbilical veins from fresh cords [24]. The cells were plated on gelatin-coated culture dishes in M199 medium containing 20\% heat-inactivated fetal bovine serum (FBS), ECGS (Endothelial Cells Growth Supplement, $50 \mu \mathrm{g} / \mathrm{mL})$, heparin $(100 \mu \mathrm{g} / \mathrm{mL})$ and antibiotics. Replicated cultures were obtained by trypsinization and only early passages (1-4) were used. Eight TC lines were used in this study: T24 cell line and TCCSUP (bladder carcinoma), MCF7 and MDA-MB-435S cells (breast adenocarcinoma), A549 and Calu-6 cells (lung carcinoma) and RKO cells (colon adenocarcinoma) were obtained from ATTC (Rockville, USA). DAG-1 (bladder carcinoma) was kindly provided by Dr Pierre Champelovier [25]. Bladder, lung and colon cell lines TCs were cultured respectively in RPMI 1640 and DMEM medium supplemented with $10 \%$ fetal bovine serum and antibiotics. Breast cell lines were cultured in DMEM F-12 medium supplemented with 10\% fetal bovine serum. Cultures were kept at $37^{\circ} \mathrm{C}$ in a $5 \% \mathrm{CO}_{2}$ humidified atmosphere. Coculture experiments were performed in HUVEC medium because primary endothelial cells are more sensitive to medium change than tumor cell lines. We make sure that TCs culture in M199 medium had no effect on CAM expression compared to the usual TC medium (data not shown).

TC as well as TC-EC coculture conditioned medium were prepared either by incubating T24 cells in M199 medium $\left(\sim 1.6 \times 10^{5}\right.$ cells $\left./ \mathrm{ml}\right)$ for $5 \mathrm{~h}$, or by incubating HUVEC-T24 cells coculture in M199 medium $\left(\sim 3.3 \times 10^{5}\right.$ cells $\left./ \mathrm{ml}\right)$ for $5 \mathrm{~h}$. The medium was then removed, centrifuged (1300 rpm, $5 \mathrm{~min}$ ) and filtered with a $0.22-\mu \mathrm{m}$ filter. HUVECs were then incubated with the corresponding conditioned medium for $5 \mathrm{~h}$. All cells were cultured at $37^{\circ} \mathrm{C}$ in a humidified atmosphere with $5 \% \mathrm{CO}_{2}$.

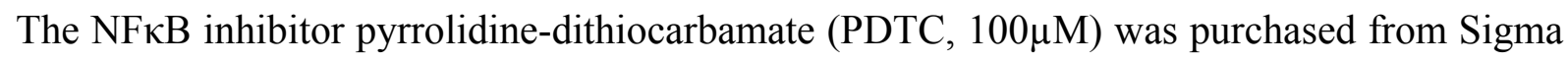
Aldrich and used at $100 \mu \mathrm{M}$ concentration. The recombinant human TNF $\alpha$ was purchased 
from Strathmann biotec AG (Germany). The cytoplasmic dye Cell Tracker Green (CTG) was purchased from Invitrogen (USA).

\section{Antibodies, plasmids}

Mouse monoclonal antibodies to VCAM-1 and E-selectin (Becton Dickinson, France), ICAM-1 [26] and IкB $\alpha$ (sc-1643, Santa Cruz, CA) were used at a $5 \mu \mathrm{g} / \mathrm{mL}$ concentration. The plasmid expressing GFP (pEGFP-N2) was obtained from Clontech BD and transfected into T24 cells using lipofectamine 2000 (Invitrogen).

\section{Immunoassay for $T N F \alpha$}

TCs were incubated for 12,24 and $48 \mathrm{~h}$ in complete culture medium. At the end of the incubation time, supernatants were collected, centrifuged at room temperature for $10 \mathrm{~min}$ at $1500 \mathrm{~g}$ in order to remove cellular debris, and stored at $-80^{\circ} \mathrm{C}$ until analysis of TNF $\alpha$ levels. Concentrations of human $\mathrm{TNF} \alpha$ in cell culture supernatants of tumor cell lines were determined in triplicates with a colorimetric sandwich enzyme linked immunosorbent assay (PromoCell, Heidelberg, Germany), following the manufacturer's instructions.

\section{FACS analysis of CAMs expression in TC/EC cocultures}

To easily distinguish TCs from ECs, TCs were labeled with the cytoplasmic dye Cell Tracker Green $(20 \mu \mathrm{M}, 20 \mathrm{~min})$. For T24 cells, we have developed a stable transfectant cell line expressing GFP which was used for the majority of experiments performed in this paper. Labeled TCs $\left(5.10^{5}\right.$ cells $)$ were cocultured on an endothelial monolayer $\left(5.10^{5}\right.$ cells $)$ for 5 hours in HUVEC medium. Cells were trypsinized, then incubated with appropriate antibodies (1h), followed by phycoerythrin-conjugated goat anti-mouse antibody (30min). FACS analysis (FACScan flow cytometer Becton Dickinson) was performed to examine CAM 
levels on the EC and TC surfaces. Quantification was made by measuring the geometric mean fluorescence.

\section{Determination of cell adhesion by flow cytometry}

HUVECs $\left(5.10^{5}\right)$ were seeded in triplicates in a 6 -well plate precoated with gelatin $2 \%$ and grown to confluency for $48 \mathrm{~h}$. In some cases HUVECs were stimulated with $\mathrm{TNF} \alpha(0.5 \mathrm{U} / \mathrm{mL}$, $5 \mathrm{~h})$, and with the appropriate blocking antibodies $(20 \mu \mathrm{g} / \mathrm{mL}, 30 \mathrm{~min})$. Subsequently $5.10^{5}$ T24-GFP cells were added per well and incubated for 5 hours $\left(37{ }^{\circ} \mathrm{C}\right.$ and $\left.5 \% \mathrm{CO}_{2}\right)$ in the presence of the same blocking antibody. At the end of the assay, wells were washed twice with Phosphate Buffered Saline (PBS). Samples were trypsinized and the number of adherent T24-GFP cells was determined using flow cytometry.

\section{Transendothelial cell migration}

Cell migration was assayed using a modified Boyden chamber assay. HUVECs $\left(1,5.10^{4}\right)$ were grown to confluence $(48 \mathrm{~h})$ on a $3 \mu \mathrm{m}$-pore size polycarbonate membrane (treated with fibronectin at $20 \mu \mathrm{g} / \mathrm{mL}$ ) separating the two compartments of a migration chamber (Transwell, Becton Dickinson, $6.5 \mathrm{~mm}$ diameter). HUVECs were treated or not with $100 \mathrm{U} / \mathrm{mL}$ TNF $\alpha$ (24h). Thereafter, EC monolayers were rinsed before T24-GFP addition. After 5h-coculture, cells on the upper face of the membrane were scraped using a cotton swab. TCs that migrated to the lower face of the filter were lysed by PBS-Triton $1 \%$. The migrating cells were quantified by measuring the GFP fluorescence emission using a fluorometer (Fluoroskan Ascent, Labsystems).

\section{Microscopy and immunofluorescence staining}

T24 cells were incubated on a HUVEC monolayer for 5 hours. Cells were fixed with $2 \%$ paraformaldehyde, then permeabilized with $0.5 \%$ Triton $\mathrm{X}-100$, stained with anti ICAM-1, 
and incubated with Alexa fluor 488-conjugated goat anti-mouse IgG (Molecular Probes) before confocal microscopy observations (Zeiss LSM510, NLO).

\section{Immunoblot Analysis}

$5.10^{5}$ ECs were cultured on a gelatin-coated 6-well plate (48h). An equal number of TCs was deposited on the endothelial monolayer and cocultured for $5 \mathrm{~h}$. After washing, about $50 \%$ of the total added TCs adhered to the EC monolayer which represents a 1 TC for 2 ECs ratio. Therefore, to prepare samples for 0h of coculture, TCs and ECs were collected separately, and then mixed together (with a ratio of $1 \mathrm{TC}$ for $2 \mathrm{ECs}$ ) before lysis and immunoblot analysis. Protein samples were separated by SDS-PAGE 10\%. Blots were probed with antibodies and developed with ECL reagents. For quantification, the blots were analyzed using ImageJ software (NIH Image, Bethesda, USA) and quantification was based on the pixel value of each band.

\section{Laminar flow assays}

A parallel-plate flow chamber providing a laminar flow was used, as previously described [27]. The wall shear stress ranged from $0.9 \pm 0.2$ to $18 \pm 4$ dynes $/ \mathrm{cm}^{2}$. To test the regulatory effect of shear stress on the coculture-induced CAM expressions in ECs, HUVECs monolayers were incubated under static conditions for $24 \mathrm{~h}$ or exposed to flow for $24 \mathrm{~h}$, or exposed to flow for $19 \mathrm{~h}$ before coculture with T24-GFP for $5 \mathrm{~h}$ under different flow conditions (0.9 to 18 dynes $\left./ \mathrm{cm}^{2}\right)$. The final concentration $\left(4.10^{6}\right.$ cells $\left./ \mathrm{mL}\right)$ of the T24-GFP suspension injected in the flow loop was calculated to obtain a constant ratio of 1EC for $1 \mathrm{TC}$ in the flow chamber during coculture experiments. TCs were allowed to settle down and adhere to the EC monolayer for $15 \mathrm{~min}$ under static conditions and then exposed to flow. In additional experiments, the effect of shear stress on the TNF $\alpha$-induced protein expression was studied by subjecting ECs to flow for $19 \mathrm{~h}$ before TNF $\alpha$-stimulation $(100 \mathrm{U} / \mathrm{mL})$ for $5 \mathrm{~h}$ under identical 
flow conditions. To determine the implication of NFאB signaling pathways in the cocultureinduced CAMs over-expression under flow, ECs were presheared $18 \mathrm{~h}$ at 9 dynes $/ \mathrm{cm}^{2}$, then treated with PDTC $(100 \mu \mathrm{M}, 1 \mathrm{~h})$ under the same flow condition, prior to 5h-coculture at 9 dynes $/ \mathrm{cm}^{2}$.

At the end of the flow assays, cells were trypsinized, and the CAM levels on cell surfaces were determined using flow cytometry and western blot analysis. 


\section{Results}

Endothelial ICAM-1 is up-regulated during HUVEC-T24 bladder carcinoma cells coculture

To investigate the effect of TC-EC interaction on CAM expression, bladder carcinoma cell line T24 was added to a Human Umbilical Vein Endothelial Cell (HUVEC) monolayer and cocultured for five hours. After washing, cells were collected and probed with an anti-ICAM1 monoclonal antibody. FACS analysis (Figure 1a-c) was carried out to determine ICAM-1 expression levels for each cell population and to quantify adherent TCs. Fluorescent TCs were used to easily distinguish each cellular type (cf. materials and methods). Both cell types express a low level of ICAM-1 under basal conditions (Figure 1a and b), this expression being increased by cytokines such as TNF $\alpha$.

Figure 1c represents the pattern obtained by flow cytometry from a 5h-coculture of ECs and T24-GFP. In this typical experiment, T24-GFP adherent cells represent $44 \%$ of total initially added TCs. Figure 1d shows the endothelial ICAM-1 levels before (black) and after (gray) coculture; the fluorescence intensity of the gray curve is significantly higher than the fluorescence intensity of the black one, indicating an increase of ICAM-1 expression in ECs after coculture. Figure 1e shows the tumoral ICAM-1 levels before (black) and after (gray) coculture; in this case, fluorescence intensity is similar for both curves, indicating no change of ICAM-1 expression in TCs after coculture. In conclusion, a fourfold increase of ICAM-1 expression was observed on ECs (Figure 1d), but no change was detected on TCs (Figure 1e).

Using confocal microscopy, resting ECs displayed a weak ICAM-1 expression (Figure 1f), whereas, after 5h-coculture, a strong expression of endothelial ICAM-1 was detected (Figure 1g). Western blot analysis confirmed this up-regulation in ICAM-1 expression after coculture (Figure 1h), with a fourfold increase when compared to ICAM-1 expression on resting 
HUVECs. These data clearly indicate that HUVEC-T24 cells interactions stimulate the expression of ICAM-1 on ECs, but not on T24 cells.

\section{Endothelial VCAM-1 and E-selectin are also over-expressed during HUVEC-T24 coculture} Considering that endothelial ICAM-1 expression was induced by T24-EC coculture (Figure 1), we further investigated the modulation of other CAMs expression. HUVECs and T24 cells cocultured for $5 \mathrm{~h}$ were collected and then analyzed for E-selectin, ICAM-1, VCAM-1, PECAM-1, VE- and N-cadherin, $\beta 1$ and $\beta 3$ integrin expression by FACS analysis. No change in tumoral CAM expression was observed after 5h-coculture (supplementary data, Figure S1), whereas only three endothelial CAMs were up-regulated: ICAM-1, VCAM-1 and E-selectin (Figure 2).

\section{Characterization of CAM up-regulation induced by HUVEC-T24 coculture}

We next investigated whether this CAM over-expression depends on the number of TCs (T24) in contact with ECs. Therefore, we analyzed ICAM-1, VCAM-1 and E-selectin expression levels for different numbers of TCs added (from $5.10^{4}$ to $1.10^{6} \mathrm{TCs}$ ) to HUVEC monolayers, and cocultured for $5 \mathrm{~h}$ (Figure 3a). Protein expression levels were determined by FACS analysis. As shown in Figure 3a, endothelial ICAM-1, VCAM-1 and E-selectin expression increased as a function of TC number. E-selectin reached its maximum expression for $4.10^{5}$ TCs whereas ICAM-1 and VCAM-1 reached their maximum expression for roughly $8.10^{5}$ TCs. For all the following experiments, a TC/EC ratio of one was used $\left(5.10^{5} \mathrm{TCs}\right.$ for $\left.5.10^{5} \mathrm{ECs}\right)$

We then determined ICAM-1, VCAM-1 and E-selectin expression kinetics during TC-EC coculture (Figure 3b). CAM over-expression started after $2 \mathrm{~h}$ coculture, reaching a plateau after $5 \mathrm{~h}$. In contrast, PECAM-1 levels were not changed during this $5 \mathrm{~h}$ experiment. 
This coculture-induced CAM over-expression is very similar to that observed in HUVEC stimulated with cytokines such as LPS or TNF $\alpha$ [28], suggesting the involvement of the same signaling pathway. Therefore, we investigated whether coculture-induced CAM overexpression kinetics could be reproduced with a low concentration of TNFa. For this experiment, confluent HUVEC monolayers were stimulated with various concentrations of TNF $\alpha$, ranging from 0.2 to $200 \mathrm{U} / \mathrm{mL}$. ICAM-1 expression was determined after 5 hours of TNF $\alpha$ stimulation by FACS analysis (supplementary data, Figure S2). We determined that a concentration of $0.5 \mathrm{U} / \mathrm{mL}$ of TNF $\alpha$ induced a similar ICAM-1 increase (about fourfold increase) as the one obtained under coculture conditions, while the maximal expression of ICAM-1 was reached for $12.5 \mathrm{U} / \mathrm{mL}$ of TNF $\alpha$.

Endothelial ICAM-1 expression kinetics were then determined either with the selected dose of $0.5 \mathrm{U} / \mathrm{mL} \mathrm{TNF} \alpha$, or after TC-EC coculture. Both stimulation modes induced similar kinetics pattern with a plateau beginning after $5 \mathrm{~h}$ (Figure 3c). Similar results were obtained for VCAM-1 and E-selectin kinetics (supplementary data, Figure S2).

\section{ICAM-1, VCAM-1 and E-selectin over-expression requires a close HUVEC-T24 contact}

Since coculture-induced CAMs over-expression kinetics was similar to TNF $\alpha$-induced CAMs kinetics, we hypothesized that a soluble molecule might be involved. To investigate whether TC-EC contact induces cytokines production, confluent HUVECs were cultured in insert with a T24-HUVEC coculture in the lower compartment (coculture+HUVEC in insert) for 5h. TCs production of cytokines was tested by separating ECs from TCs in the Transwell (T24+HUVEC in insert). Then the selected ECs (dotted line in Figure 4) were analyzed for CAM expression by flow cytometry. Figure 4 shows that endothelial ICAM-1, VCAM-1 and E-selectin were up-regulated only when TCs were in tight contact with the HUVEC monolayer. We also tested if a low concentration of TNF $\alpha$, which might be secreted by TCs or TC-EC contact, was able to stimulate ECs in another compartment. HUVECs were 
cultured on the upper compartment of a Transwell $(0.4 \mu \mathrm{m}$ pore, 6 -well plate) with TNF $\alpha(0.5$ $\mathrm{U} / \mathrm{mL}$ ) inside the lower compartment. Five hours later, HUVECs displayed a significant overexpression of ICAM-1, VCAM-1 and E-selectin (Figure 4), showing that in our test, a low concentration of soluble molecules can cross the filter and stimulate ECs. Similar results were obtained after $24 \mathrm{~h}$ using the same test (supplementary data, Figure S4). To further confirm that the ICAM-1 increase expression was not induced by a soluble factor released by TCs, we performed two additional experiments: we prepared conditioned medium either from TCs alone or from a TC-EC coculture. These conditioned media were then added to ECs for $5 \mathrm{~h}$. In both cases, no increase in ICAM-1 expression was detected (supplementary data, Figure S5). We also quantified TNF $\alpha$ secretion by TCs. TNF $\alpha$ protein concentrations in culture supernatants were assessed by ELISA after a 12, 24 or $48 \mathrm{~h}$ incubation time. Four cell lines were tested for TNF $\alpha$ production. T24 and MDA, which were able to increase endothelial ICAM-1 expression after coculture (as shown in table 1), and TCC-Sup and DAG-1, which did not induce any modification in endothelial ICAM-1 expression in coculture. TNF $\alpha$ protein concentrations remained below the detection limit of the ELISA assay $\left(<15 \mathrm{pg} / \mathrm{ml}\right.$ for $10^{6}$ cells) for all cell lines (data not shown). Therefore, as strongly suggested by the transwell assays (Fig. 4 and Fig S4) and the conditioned medium experiment (Fig S5), the increase in endothelial ICAM-1 expression is not mediated by TNF $\alpha$ secreted by TCs. All together, these data clearly demonstrate that coculture-induced CAM overexpression required a tight contact between TCs and HUVECs and was not due to a soluble factor such as TNFa.

\section{HUVEC-T24 coculture-induced CAM over-expression depends on NFkB signaling}

\section{pathway}

ICAM-1, VCAM-1 and E-selectin are mainly regulated by the transcription factor NFאB [29]. To determine whether NFאB is activated in HUVECs after contact with TCs, HUVECs were treated with the NFאB inhibitor pyrrolidine-dithiocarbamate (PDTC), prior to 5h-coculture, 
and the ICAM-1 expression was analyzed by flow cytometry. PDTC is an antioxidant which has been shown to be an effective inhibitor of NFKB activation, presumably working through the inhibition of IאB degradation [30-32]. Treatment of HUVECs with PDTC fully prevented the expression of endothelial ICAM-1 induced by coculture or by TNF $\alpha$ treatment (Figure 5). This suggests that both coculture and $\mathrm{TNF} \alpha$ may trigger similar pathways via the activation of the NFkB transcription factor.

\section{Effect of CAM expression on T24 cell adhesion and transendothelial migration}

We then studied the involvement of endothelial ICAM-1, VCAM-1 and E-selectin on the adhesion of T24 cells to HUVEC monolayers. HUVECs stimulated or not with $0.5 \mathrm{U} / \mathrm{mL}$ TNF $\alpha$ were preincubated with the appropriate blocking antibodies: anti-ICAM-1, antiVCAM-1 and anti-E-selectin. Suspensions of T24-GFP cells were added to monolayers for $5 \mathrm{~h}$ in the presence of the same blocking antibody and adherent T24-GFP cells were quantified using flow cytometry. Note that in these experiments we define the "percentage of adherent TCs" as the percentage of TC which attached or spread on the endothelial monolayer after $5 \mathrm{~h}$ coculture.

With unstimulated HUVECs (Figure 6a), inhibition of endothelial ICAM-1, VCAM-1 and Eselectin had no effect on T24 cell adhesion, with about $60 \%$ of adherent cells. TNF $\alpha$ treatment of HUVEC monolayers induced a $20 \%$ increase in the number of adherent TCs when compared to unstimulated HUVECs. VCAM-1 inhibition resulted in a detectable decrease of $25 \%$ of $\mathrm{T} 24$ adherent cells to $\mathrm{TNF} \alpha$-stimulated ECs, whereas ICAM-1 and E-selectin inhibition had no influence on TC adhesion (Figure 6a).

We next investigated whether ICAM-1, VCAM-1 or E-selectin could also be involved in T24 cells transmigration (Figure 6b). With unstimulated HUVECs (Figure 6b), inhibition of endothelial ICAM-1 resulted in a significant decrease of the percentage of TCs transmigrated 
$(19 \pm 3 \%$ versus $26 \pm 3 \%)$. VCAM-1 or E-selectin inhibition had no effect on TC migration through untreated EC monolayers.

With stimulated HUVECs, TC transmigration increased $(39 \pm 6 \%$ in TNF $\alpha$ treated HUVECs versus $26 \pm 3 \%$ in unstimulated HUVECs) and this transendothelial migration was strongly reduced when endothelial ICAM-1 was blocked ( $19 \pm 5 \%$ versus $39 \pm 6 \%$ ), suggesting a major role for ICAM-1 in T24 cells transmigration. Furthermore, inhibition of VCAM-1 significantly reduced the percentage of T24 cells transmigration through TNF $\alpha$-stimulated HUVECs $(27 \pm 5 \%$ versus $39 \pm 6 \%)$. This is likely due to the involvement of VCAM-1 in TC adhesion on TNF $\alpha$-stimulated HUVECs (Figure 6a). On the other hand, E-selectin inhibition had no effect on transmigration.

\section{Effect of other carcinoma cell lines on endothelial CAM expression}

Throughout this study, our data indicated that direct contact between HUVECs and bladder carcinoma cell line T24 induced endothelial ICAM-1, VCAM-1 and E-selectin up-regulation via NFkB transcription factor activation. We next explored whether other human carcinoma cell lines could induce endothelial CAM over-expression during coculture. Therefore, two bladder carcinoma cell lines (DAG-1 and TCCSUP), two breast adenocarcinoma cell lines (MCF7 and MDA-MB-435S), two lung carcinoma cell lines (A549 and Calu-6), and one colon adenocarcinoma cell line (RKO) were tested (cf. materials and methods). HUVEC monolayers were cocultured during $5 \mathrm{~h}$ in contact with the different fluorescently labeled TCs and ICAM-1 expression was analyzed by flow cytometry.

Among this panel of TC lines, only T24 cells and MDA-MB-435S were able to induce endothelial CAM over-expression after coculture, with a fourfold increase on average (Table 1). This suggests that the observed CAM over-expression is cell type dependent. 


\section{Shear stress differentially modulates the HUVEC-T24 coculture-induced CAM expression}

\section{in ECs}

Under physiological conditions, ECs are constantly subjected to hemodynamic forces. To investigate the effect of shear stress on coculture-induced CAM expression, we used a parallel-plate flow chamber (cf. materials and methods). The EC monolayer was inserted into the flow chamber and presheared at $0.9,9$ or 18 dynes $/ \mathrm{cm}^{2}$ for $19 \mathrm{~h}$. A suspension of T24 cells was then perfused through the chamber, allowed to settle down for $15 \mathrm{~min}$, and cells were exposed to a constant shear stress $\left(0.9,9\right.$ or 18 dynes $\left./ \mathrm{cm}^{2}\right)$ for $5 \mathrm{~h}$. The effect of flow on the TNF $\alpha$-induced CAM expression was also studied under the same conditions, with TNF $\alpha$ added for the last $5 \mathrm{~h}$. At the end of assays, ICAM-1, VCAM-1 and E-selectin expressions were analyzed by flow cytometry. As shown in Figure 7a, with unstimulated ECs in the absence of TCs, ICAM-1 expression increased as a function of shear stress intensity, whereas VCAM-1 or E-selectin expression levels were unchanged (Figure 7b-c). Under Moderate Shear Stress (MSS) conditions $\left(\leq 9 \mathrm{dynes} / \mathrm{cm}^{2}\right), 5 \mathrm{~h}$-coculture induced a significant increase in endothelial ICAM-1, VCAM-1 and E-selectin levels (Figures 7a-c) as already observed under static conditions (Figure 2). In contrast, under High Shear Stresses (HSS) of 18 dynes $/ \mathrm{cm}^{2}$, TC-EC coculture did not induce any modification of CAMs expression (Figure 7a-c), as confirmed by the western blot analysis for ICAM-1 (Figure 7e). In accordance with our previous report [23], the percentage of attached TCs on the EC monolayer after 5h hours coculture significantly decreased (from $57 \pm 8 \%$ to $21 \pm 9 \%$ ) when the shear flow increased from 0.9 to 9 dynes $/ \mathrm{cm}^{2}$, and remained stable (from $21 \pm 9 \%$ to $22 \pm 7 \%$ ) when the shear increased from 9 to 18 dynes $/ \mathrm{cm}^{2}$, (supplementary data S3). This indicates that the absence of cocultureinduced CAM expression under HSS was not due to a lack of TCs attached to the endothelial layer. Furthermore, HSS also inhibited the TNF $\alpha$-induced CAMs over-expression, whereas the TNF $\alpha$-stimulated HUVECs under MSS displayed a significant increase in ICAM-1, VCAM-1 and E-selectin expressions (Figure 7a-c). 
Our findings thus identify HSS as an inhibitor of CAM expression in TNF $\alpha$-stimulated HUVECs as well as in ECs cocultured with T24 cells. This confirms the existence of a shear stress threshold above which flow acts as an anti-inflammatory agent [33]. As already observed under static conditions (Figure 5), the over-expression under MSS was dependent upon the activation of the NFאB signaling pathway, since PDTC treated HUVECs cocultured with TCs and exposed to a shear stress of 9 dynes $/ \mathrm{cm}^{2}$ did not display any CAMs upregulation (Figure 7d). Preshearing of ECs at $18 \mathrm{dynes} / \mathrm{cm}^{2}$ (but not at $9 \mathrm{dynes} / \mathrm{cm}^{2}$, nor under static condition) significantly inhibited the decrease in $\mathrm{I} \kappa \mathrm{B} \alpha$ protein expression induced by TC-EC coculture (Figure 7f). When compared to static ECs, inhibition of endothelial NFkB signaling pathway by PDTC blocked I $\mathrm{B} \alpha$ degradation after TC-EC coculture under flow conditions. 


\section{Discussion}

Extravasation of TCs is a complex process involving adhesive interactions [34, 35]. Stimulation of ECs induced by contact with other cells has already been reported by several authors. Kokura et al. [36] showed that close contact between T lymphocytes and HUVECs induced endothelial TNF $\alpha$ and IL-8 production in a post anoxic model. Damle et al. [37] showed that interactions between ECs and subpopulations of human $\mathrm{T}$ cells induced endothelial CAMs expression, and this required direct intercellular contact. Other studies showed that the coculture of ECs and TCs induced tumoral N-cadherin over-expression [38], and transient down-regulation of tumoral $\alpha 2, \alpha 3$ and $\alpha 5$ integrins [39], altering cell migration. In our model, no change in tumoral CAM expression was observed after 5h-coculture, whereas endothelial ICAM-1, VCAM-1 and E-selectin were highly increased under static and MSS conditions. Other studies have shown that TCs are able to induce cell activation in heterotypic coculture. Mierke et al [40] showed that endothelial cells cocultured with invasive tumor cells increased chemokine gene expression of IL-8 and Gro- $\beta$. Peng et al [41] demonstrated that IL-8 is up-regulated in PMNs upon co-culturing with melanoma cells, and this facilitates melanoma cell migration through the endothelium under flow conditions. Since heterotypic cell-cell interactions between T24 cells and ECs stimulate the expression of endothelial CAMs, we postulated that this phenomenon may influence T24 cell adhesion and transmigration. Using monoclonal antibodies, we showed that ICAM-1 and VCAM-1 facilitate T24 cells transendothelial migration whereas VCAM-1 plays a role in T24 cells adhesion. It is likely that VCAM-1 implication in both transmigration and adhesion are linked. It is now established that CAMs mediate TC and leukocyte diapedesis through EC monolayers. For example, VCAM-1 was up-regulated on activated ECs and promoted transendothelial migration of leukocytes [42]. Recently, Klemke et al. [43] demonstrated that transendothelial migration of highly metastatic melanoma cell lines depended on VCAM- 
1/VLA-4 interaction. Yang et al. [44] showed that ICAM-1 regulates neutrophil transendothelial migration of vascular endothelium under dynamic conditions.

In our conditions, ICAM-1, VCAM-1 and E-selectin expressions displayed similar kinetic patterns in HUVECs cocultured with T24 cells and in TNF $\alpha$-stimulated HUVECs, suggesting the involvement of a common signaling pathway. It is well known that vascular endothelium is a major target for proinflammatory cytokines such as TNF $\alpha$. Many signaling events are initiated by the binding of TNF $\alpha$ to one of its two cell surface receptors TNFR-1 and TNFR-2 [45] leading to nuclear translocation of NFאB and transcription of target genes [46]. After TNF $\alpha$ stimulation of ECs, NFאB binds to a specific region in the ICAM-1, VCAM-1 and Eselectin gene promoters, inducing their respective transcription [29, 47]. Here, we showed that the NFKB signaling pathway is likely involved in coculture-induced endothelial ICAM-1, VCAM-1 and E-selectin expressions under static and MSS conditions. This is in agreement with Ohno et al. [48] who showed similarly that NFkB inhibition in ECs reduced the adhesion between HUVEC and HT-29 colon cancer cells under static and flow conditions (6 dynes $\left./ \mathrm{cm}^{2}\right)$.

In addition, we observed that flow-induced endothelial ICAM-1 up-regulation was dependent on the level of shear stress. This is in agreement with Tsuboi et al. [14] who demonstrated a modulating effect of shear stress on flow-induced endothelial ICAM-1 expression. An important finding of the current study is that the level of shear stress (HSS: 18 dynes $/ \mathrm{cm}^{2}$ versus MSS: 0.9 and 9 dynes $/ \mathrm{cm}^{2}$ ) modulates the response of EC gene expression to TC coculture as well as to TNF $\alpha$ stimulation. HSS totally ruled out the coculture-induced as well as TNF $\alpha$-induced expressions of ICAM-1, VCAM-1, and E-selectin in ECs; this suggests that HSS, in addition to its anti-inflammatory role, regulates the response of T24 adherent cells. Such a phenomenon has already been shown for TNF $\alpha$. Sheikh et al [49] demonstrated that HSS (10-20dynes $/ \mathrm{cm}^{2}$ ) reduced the TNF $\alpha$-induced expression of endothelial selectins by $66 \%$ and this abolished the adhesion of neutrophils to the endothelial monolayer. The mechanism 
by which HSS inhibits EC gene expression induced by coculture or TNF $\alpha$ stimulation is unclear but is likely to be multifactorial. Chiu et al. [33] showed that HSS (12 dynes/ $\left.\mathrm{cm}^{2}\right)$ inhibited ICAM-1, VCAM-1 and E-selectin expression in vascular ECs, induced by coculture with smooth muscle cells. In this model, the authors demonstrated that the coculture-induced CAMs up-regulation was not dependent on close contact between EC and muscle cells but involved soluble factors (IL-1 $\beta$ and IL-6), acting at a small distance. This led to activation of the c-Jun-NH2-terminal kinase (JNK) and p38 MAPK and increased the NFאB promoter binding activity in ECs [50]. In our study, the endothelial ICAM-1 upregulation was dependent on TC/EC close contact and was not mediated by a soluble factor such as TNF $\alpha$ secreted by TCs. Indeed, in 5 and 24h-transwell experiments, TC conditioned medium experiments, as well as TNF $\alpha$ immunodosage assays confirmed a TC-EC contact at the origin of this coculture-induced CAM overexpression. Recent studies [51] showed that preshearing of ECs (16 dynes $/ \mathrm{cm}^{2}$ for $\left.16 \mathrm{~h}\right)$ significantly altered transcriptional responses to TNF $\alpha$ stimulation by suppressing pro-inflammatory transcripts (E-selectin, VCAM-1, IL-8) and enhanced the expression of cytoprotective molecules (Bcl-2, MnSOD, GADD45). Mohan et al. [52] also showed a differential effect of the shear stress level in human aortic ECs. These authors demonstrated that MSS $\left(2\right.$ dynes $\left./ \mathrm{cm}^{2}\right)$ induced a strong and persistent activation of NFkB (+100\% vs. static control, over $2 \mathrm{~h})$. In contrast HSS $\left(16\right.$ dynes $\left./ \mathrm{cm}^{2}\right)$ induced a weak activation of $\mathrm{NF \kappa B}(+10 \%)$ at the early times of shear stress application, and this activation dramatically decreased (-70\% vs. static control) after a few minutes. All these studies are in favour of the existence of a shear stress threshold above which flow acts as an antiinflammatory agent [33]. Such observations correlate with the fact that veins and capillaries (in which MSS are predominant) are preferential targets for metastasis [53].

Several cell lines were tested for coculture in the presence of ECs, but only the T24 (bladder carcinoma) and MDA-MB-435S cell lines (breast adenocarcinoma) were able to induce CAMs up-regulation (Table 1). T24 and MDA cells share several common characteristics. 
Both cell lines express ICAM-1 [54, 55], N-cadherin $[56,57]$, and the transcription factor E2A [58]. It has also been reported that T24 and MDA cells, which derive from epithelial tissues, do not express any E-cadherins [58]. It is known that the invasion process involves the loss of cell-cell interactions with the gain of migratory properties [59]. E-cadherin is the main adhesion molecule of epithelia $[60,61]$, and it has been implicated in carcinogenesis because it is frequently lost in human epithelial tumors [62, 63]. Perez-Moreno et al. [58] indeed showed an implication of E2A transcription factor as a repressor of E-cadherin expression during tumor progression in MDA and T24 cells. The cytoplasmic domain of Ecadherin generates complexes with many signaling molecules, including $\alpha-, \beta$-, and $\gamma$-catenin, p120ctn, and Shc. This common phenotype shared by T24 and MDA cell lines may explain their similar coculture-induced endothelial CAM over-expression. Further investigations using gene transfection are needed to determine the potential implication of E-cadherin in this phenomenon.

To sum up, our study indicates that tight contact between T24 and HUVECs upregulates ICAM-1, VCAM-1 and E-selectin expression under static and MSS conditions, whereas, the application of HSS inhibits these coculture-induced as well as TNF $\alpha$-induced CAMs overexpressions. This CAM upregulation is NFkB-dependent and increases T24 cell adhesion and transmigration. Further investigations are needed to understand the molecular mechanisms involved in this coculture-induced CAM expression. 


\section{Acknowledgements}

We gratefully acknowledge Remy Pedeux for helpful discussions and critical reading of the manuscript and Alexeï Grichine for his assistance with the confocal microscope. We thank the workshop of "Laboratoire de Spectrométrie Physique" for the flow chamber design. This work has been partly supported by "La ligue contre le cancer" and the RTN project funded by the EU (contract $\left.\mathrm{N}^{\circ} \mathrm{CT}-2000-00105\right)$. 


\section{References}

[1] I.J. Fidler, The pathogenesis of cancer metastasis: the 'seed and soil' hypothesis revisited, Nat. Rev. Cancer. 3 (2003) 453-458.

[2] G. Christofori, Changing neighbours, changing behaviour: cell adhesion moleculemediated signalling during tumour progression, Embo. J. 22 (2003) 2318-2323.

[3] A. Takada, K. Ohmori, T. Yoneda, K. Tsuyuoka, A. Hasegawa, M. Kiso, R. Kannagi, Contribution of carbohydrate antigens sialyl Lewis A and sialyl Lewis $\mathrm{X}$ to adhesion of human cancer cells to vascular endothelium, Cancer. Res. 53 (1993) 354-361.

[4] T.H. Schreiber, V. Shinder, D.W. Cain, R. Alon, R. Sackstein, Shear flow-dependent integration of apical and subendothelial chemokines in T-cell transmigration: implications for locomotion and the multistep paradigm, Blood. 109 (2007) 13811386.

[5] L. Osborn, Leukocyte adhesion to endothelium in inflammation, Cell. 62 (1990) 3-6.

[6] R. Giavazzi, M. Foppolo, R. Dossi, A. Remuzzi, Rolling and adhesion of human tumor cells on vascular endothelium under physiological flow conditions. J. Clin. Invest. 92 (1993) 3038-3044.

[7] A.F. Chambers, E.E. Schmidt, I.C. MacDonald, V.L. Morris, A.C. Groom, Early steps in hematogenous metastasis of B16F1 melanoma cells in chick embryos studied by highresolution intravital videomicroscopy, J. Natl. Cancer. Inst. 84 (1992) 797-803.

[8] F.W. Orr, H.H. Wang, R.M. Lafrenie, S. Scherbarth, D.M. Nance, Interactions between cancer cells and the endothelium in metastasis, J. Pathol. 190 (2000) 310-329.

[9] C. Strell, K. Lang, B. Niggemann, K.S. Zaenker, F. Entschladen, Surface molecules regulating rolling and adhesion to endothelium of neutrophil granulocytes and MDAMB-468 breast carcinoma cells and their interaction, Cell. Mol. Life. Sci. 64 (2007) 3306-3316. 
[10] C.F. Dewey, Jr., S.R. Bussolari, M.A. Jr Gimbrone, P.F. Davies, The dynamic response of vascular endothelial cells to fluid shear stress. J. Biomech. Eng. 103 (1981) 177185.

[11] C.G. Galbraith, R. Skalak, S. Chien, Shear stress induces spatial reorganization of the endothelial cell cytoskeleton, Cell. Motil. Cytoskeleton. 40 (1998) 317-330.

[12] J.J. Chiu, P.L Lee, C.N Chen, C.I Lee, S.F Chang, L.J Chen, S.C Lien, Y.C Ko, S. Usami, S. Chien, Shear stress increases ICAM-1 and decreases VCAM-1 and Eselectin expressions induced by tumor necrosis factor-[alpha] in endothelial cells. Arterioscler. Thromb. Vasc. Biol. 24 (2004) 73-79.

[13] H.W. Sun, C.J. Li, H.Q. Chen, H.L. Lin, H.X. Lv, Y. Zhang, M. Zhang. Biochem Biophys Res Commun, 353 (2007) 152-158.

[14] H. Tsuboi, J. Ando, R. Korenaga, Y. Takada, A. Kamiya, Involvement of integrins, MAPK, and NF-kappaB in regulation of the shear stress-induced MMP-9 expression in endothelial cells, Biochem. Biophys. Res. Commun. 206 (1995) 988-996.

[15] B. Imberti, M. Morigi, C. Zoja, S. Angioletti, M. Abbate, A. Remuzzi, G. Remuzzi, Shear stress-induced cytoskeleton rearrangement mediates NF-kappaB-dependent endothelial expression of ICAM-1, Microvasc. Res. 60 (2000) 182-188.

[16] S. Scherbarth, F.W. Orr, Intravital videomicroscopic evidence for regulation of metastasis by the hepatic microvasculature: effects of interleukin-1alpha on metastasis and the location of B16F1 melanoma cell arrest, Cancer. Res. 57 (1997) 4105-4110.

[17] A.S. Jr. Baldwin, Series introduction: the transcription factor NF-kappaB and human disease, J. Clin. Invest. 107 (2001) 3-6.

[18] N.S. Trede, A.V. Tsytsykova, T. Chatila, A.E. Goldfeld, R.S. Geha, Transcriptional activation of the human TNF-alpha promoter by superantigen in human monocytic cells: role of NF-kappa B, J. Immunol. 155 (1995) 902-908. 
[19] C. Chen, C. Chou, Y. Sun, W. Huang, Tumor necrosis factor alpha-induced activation of downstream NF-kappaB site of the promoter mediates epithelial ICAM-1 expression and monocyte adhesion. Involvement of PKCalpha, tyrosine kinase, and IKK2, but not MAPKs, pathway, Cell. Signal. 13 (2001) 543-553.

[20] M.F. Iademarco, J.J. McQuillan, G.D. Rosen, D.C. Dean, Characterization of the promoter for vascular cell adhesion molecule-1 (VCAM-1), J. Biol. Chem. 267 (1992) 16323-16329.

[21] A.S. Neish, A.J. Williams, H.J. Palmer, M.Z. Whitley, T. Collins, Functional analysis of the human vascular cell adhesion molecule 1 promoter, J. Exp. Med. 176 (1992) 15831593.

[22] J. Whelan, P. Ghersa, R. Hooft van Huijsduijnen, J. Gray, G. Chandra, F. Talabot, J.F. DeLamarter, An NF kappa B-like factor is essential but not sufficient for cytokine induction of endothelial leukocyte adhesion molecule 1 (ELAM-1) gene transcription, Nucleic. Acids. Res. 19 (1991) 2645-2653.

[23] R. Chotard-Ghodsnia, O. Haddad, A. Leyrat, A. Drochon, C. Verdier, A. Duperray, Morphological analysis of tumor cell/endothelial cell interactions under shear flow, J. Biomech. 40 (2007) 335-344.

[24] E.A. Jaffe, R.L. Nachman, C.G. Becker, C.R. Minick, Culture of human endothelial cells derived from umbilical veins. Identification by morphologic and immunologic criteria, J. Clin. Invest. 52 (1973) 2745-2756.

[25] P. Champelovier, A. Besse, N. Boucard, A. Simon, D. Leroux, N. Pinel, V. Praloran, D. Seigneurin, Dag-1 carcinoma cell in studying the mechanisms of progression and therapeutic resistance in bladder cancer, Eur. Urol. 39 (2001) 343-348.

[26] L.R. Languino, A. Duperray, K.J. Joganic, M. Fornaro, G.B. Thornton, D.C. Altieri, Regulation of leukocyte-endothelium interaction and leukocyte transendothelial 
migration by intercellular adhesion molecule 1-fibrinogen recognition, Proc. Natl. Acad. Sci. USA. 92 (1995) 1505-1509.

[27] R. Chotard-Ghodsnia, A. Drochon, R. Grebe, A new flow chamber for the study of shear stress and transmural pressure upon cells adhering to a porous biomaterial, J. Biomech. Eng. 124 (2002) 258-261.

[28] S. Kayal, A. Lilienbaum, C. Poyart, S. Memet, A. Israel, P. Berche, Listeriolysin Odependent activation of endothelial cells during infection with Listeria monocytogenes: activation of NF-kappa B and upregulation of adhesion molecules and chemokines, Mol. Microbiol. 31 (1999) 1709-1722.

[29] M.J. May, S. Ghosh, Signal transduction through NF-kappa B, Immunol. Today. 19 (1998) 80-88.

[30] M.R. Heitmeier, A.L. Scarim, J.A. Corbett, Double-stranded RNA-induced inducible nitoric-oxide synthase expression and interleukin-1 release by murine macrophage requires NFkB activation, J. Biol. Chem. 273 (1998) 15301-15307.

[31] S. Nakao, Y. Ogtata, E. Shimizu, M. Yamazaki, S. Furuyama, H. Sugiya, Tumor necrosis factor alpha (TNF-alpha)-induced prostaglandin E2 release is mediated by the activation of cyclooxygenase-2 (COX-2) transcription via NFkappaB in human gingival fibroblasts, Mol. Cell. Biochem. 238 (2002) 11-18.

[32] P.R. Crisostomo, Y. Wang, T.A. Markel, M. Wang, T. Lahm, D.R. Meldrum, Human mesenchymal stem cells stimulated by TNF-alpha, LPS, or hypoxia produce growth factors by an NF kappa B- but not JNK-dependent mechanism, Am. J. Physiol. Cell. Physiol. 294 (2008) 675-682.

[33] J.J. Chiu, L.J. Chen, P.L. Lee, C.I. Lee, L.W. Lo, S. Usami, S. Chien, Shear stress inhibits adhesion molecule expression in vascular endothelial cells induced by coculture with smooth muscle cells, Blood. 101 (2003) 2667-2674. 
[34] M. Sandig, E.B. Voura, V.I. Kalnins, C.H. Siu, Role of cadherins in the transendothelial migration of melanoma cells in culture, Cell. Motil. Cytoskeleton. 38 (1997) 351-364.

[35] E.B. Voura, R.A. Ramjeesingh, A.M. Montgomery, C.H. Siu, Involvement of integrin alpha(v)beta(3) and cell adhesion molecule L1 in transendothelial migration of melanoma cells, Mol. Biol. Cell. 12 (2001) 2699-2710.

[36] S. Kokura, R.E. Wolf, T. Yoshikawa, D.N. Granger, T.Y. Aw, Postanoxic T lymphocyteendothelial cell interactions induce tumor necrosis factor-alpha production and neutrophil adhesion: role of very late antigen-4/vascular cell adhesion molecule-1, Circ. Res. 86 (2000) 1237-1244.

[37] N.K. Damle, C. Eberhardt, M. Van der Vieren, Direct interaction with primed CD4+ CD45R0+ memory $\mathrm{T}$ lymphocytes induces expression of endothelial leukocyte adhesion molecule-1 and vascular cell adhesion molecule-1 on the surface of vascular endothelial cells, Eur. J. Immunol. 21 (1991) 2915-2923.

[38] J. Qi, N. Chen, J. Wang, C.H. Siu, Transendothelial migration of melanoma cells involves N-cadherin-mediated adhesion and activation of the beta-catenin signaling pathway, Mol. Biol. Cell. 16 (2005) 4386-4397.

[39] J. Jones, S. Berkhoff, E. Weich, T. Engl, S. Wedel, B. Relja, D. Jonas, R.A. Blaheta, Transient down-regulation of betal integrin subtypes on kidney carcinoma cells is induced by mechanical contact with endothelial cell membranes, J. Cell. Mol. Med. 11 (2007) 826-838.

[40] C.T. Mierke, D.P. Zitterbart, P. Kollmannsberger, C. Raupach, U. Schlötzer-Schrehardt, T.W. Goecke, J. Behrens, B. Fabry, Breakdown of the endothelial barrier function in tumor cell transmigration, Biophys. J. 94 (2008) 2832-2846.

[41] H.H. Peng, S. Liang, A.J. Henderson, C. Dong, Regulation of interleukin-8 expression in melanoma-stimulated neutrophil inflammatory response, Exp. Cell. Res. 313 (2007) 551-559. 
[42] P.Y. Chan, A. Aruffo, VLA-4 integrin mediates lymphocyte migration on the inducible endothelial cell ligand VCAM-1 and the extracellular matrix ligand fibronectin, J. Biol. Chem. 268 (1993) 24655-24664.

[43] M. Klemke, T. Weschenfelder, M.H. Konstandin, Y. Samstag, High affinity interaction of integrin alpha4beta1 (VLA-4) and vascular cell adhesion molecule 1 (VCAM-1) enhances migration of human melanoma cells across activated endothelial cell layers, J. Cell. Physiol. 212 (2007) 368-374.

[44] L. Yang, R.M. Froio, T.E. Sciuto, A.M. Dvorak, R. Alon, F.W. Luscinskas, ICAM-1 regulates neutrophil adhesion and transcellular migration of TNF-alpha-activated vascular endothelium under flow, Blood. 106 (2005) 584-592.

[45] D. Wallach, E.E. Varfolomeev, N.L. Malinin, Y.V. Goltsev, A.V. Kovalenko, M.P. Boldin, Tumor necrosis factor receptor and Fas signaling mechanisms, Annu. Rev. Immunol. 17 (1999) 331-367.

[46] A. Hoffmann, G. Natoli, G. Ghosh, Transcriptional regulation via the NF-kappaB signaling module, Oncogene. 25 (2006) 6706-6716.

[47] J. Roy, M. Audette, M.J. Tremblay, Intercellular adhesion molecule-1 (ICAM-1) gene expression in human $\mathrm{T}$ cells is regulated by phosphotyrosyl phosphatase activity. Involvement of NF-kappaB, Ets, and palindromic interferon-gamma-responsive element-binding sites, J. Biol. Chem. 276 (2001) 14553-14561.

[48] O. Ohno, Y. Shima, Y. Ikeda, K. Sakurai, K. Watanabe, Y. Kawai, K. Umezawa, Inhibition of cellular adhesion in human umbilical vein endothelial cells by NFkappaB inhibitor DHMEQ under flow, Oncol. Res. 15 (2005) 189-197.

[49] S. Sheikh, G.E. Rainger, Z. Gale, M. Rahman, G.B. Nash, Exposure to fluid shear stress modulates the ability of endothelial cells to recruit neutrophils in response to tumor necrosis factor-alpha: a basis for local variations in vascular sensitivity to inflammation, Blood. 102 (2003) 2828-2834. 
[50] J.J. Chiu, L.J. Chen, C.I. Lee, P.L. Lee, D.Y. Lee, M.C. Tsai, C.W. Lin, S. Usami, S. Chien, Mechanisms of induction of endothelial cell E-selectin expression by smooth muscle cells and its inhibition by shear stress, Blood. 110 (2007) 519-528.

[51] J. Partridge, H. Carlsen, K. Enesa, H. Chaudhury, M. Zakkar, L. Luong, A. Kinderlerer, M. Johns, R. Blomhoff, J.C. Mason, D.O. Haskard, P.C. Evans, Laminar shear stress acts as a switch to regulate divergent functions of NF-kappaB in endothelial cells, Faseb. J. 21 (2007) 3553-3561.

[52] S. Mohan, K. Koyoma, A. Thangasamy, H. Nakano, R.D. Glickman, N. Mohan, Low shear stress preferentially enhances IKK activity through selective sources of ROS for persistent activation of NF-kappaB in endothelial cells, Am. J. Physiol. Cell. Physiol. 292 (2007) C362-371.

[53] E.S. Yi, Tumors of the pulmonary vasculature, Cardiol. Clin. 22 (2004) 431-440.

[54] S. Ali, J. Kaur, K.D. Patel, Intercellular cell adhesion molecule-1, vascular cell adhesion molecule-1, and regulated on activation normal $\mathrm{T}$ cell expressed and secreted are expressed by human breast carcinoma cells and support eosinophil adhesion and activation, Am. J. Pathol. 157 (2000) 313-321.

[55] Y. Roche, D. Pasquier, J.J. Rambeaud, D. Seigneurin, A. Duperray, Fibrinogen mediates bladder cancer cell migration in an ICAM-1-dependent pathway, Thromb. Haemost. 89 (2003) 1089-1097.

[56] A. Mialhe, G. Levacher, P. Champelovier, V. Martel, M. Serres, K. Knudsen, D. Seigneurin, Expression of E-, P-, N-cadherins and catenins in human bladder carcinoma cell lines, J. Urol. 164 (2000) 826-835.

[57] P. Sillanpaa, L. Heikinheimo, V. Kataja, M. Eskelinen, V.M. Kosma, M. Uusitupa, H. Vainio, K. Metsola, A. Hirvonen, CYP1A1 and CYP1B1 genetic polymorphisms, smoking and breast cancer risk in a Finnish Caucasian population. Breast. Cancer. Res. Treat. 104 (2007) 287-297. 
[58] M.A. Perez-Moreno, A. Locascio, I. Rodrigo, G. Dhondt, F. Portillo, M.A. Nieto, A. Cano, A new role for E12/E47 in the repression of E-cadherin expression and epithelial-mesenchymal transitions, J. Biol. Chem. 276 (2001) 27424-27431.

[59] A.K. Perl, P. Wilgenbus, U. Dahl, H. Semb, G. Christofori, A causal role for E-cadherin in the transition from adenoma to carcinoma, Nature. 392 (1998) 190-193.

[60] H. Aberle, H. Schwartz, H.R. Kemler, Cadherin-catenin complex: protein interactions and their implications for cadherin function, J. Cell. Biochem. 61 (1996) 514-523.

[61] B. Geiger, O. Ayalon, Cadherins, Annu. Rev. Cell. Biol. 8 (1992) 307-332.

[62] W. Birchmeier, J. Behrens, Cadherin expression in carcinomas: role in the formation of cell junctions and the prevention of invasiveness, Biochim. Biophys. Acta. 1198 (1994) 11-26.

[63] M. Takeichi, Cadherins in cancer: implications for invasion and metastasis, Curr. Opin. Cell. Biol. 5 (1993) 806-811. 


\section{Figure legends}

Figure 1: TC-EC coculture induces endothelial ICAM-1 over-expression. FACS analysis of the mixed cell population (HUVEC and T24-GFP) collected from cocultures (a-e). ICAM1 was stained with phycoerythrin (PE)-conjugated secondary antibody (gray). (a) Endothelial cells and (b) T24-GFP cells before coculture were stained for ICAM-1. (c) A mixture of EC and T24-GFP cells (with a ratio of $1 \mathrm{TC}$ for $1 \mathrm{EC}$ ) after 5h-coculture. Quantification of ICAM-1 levels before (black) and after (gray) coculture was carried out for both cell types: (d) endothelial cells; (e) T24-GFP cells. Confocal microscopic images of resting HUVECs (f) and HUVEC monolayer cocultured with T24-GFP cells during 5 hours (g) stained for ICAM1 (gray). Immunoblots showing ICAM-1 expression after coculture (h). Samples were taken from resting HUVECs (EC), resting T24 (TC), or HUVEC-T24 coculture (Co). TCs and ECs were also cultured separately and mixed together (with a ratio of $1 \mathrm{TC}$ for $2 \mathrm{EC}$ ) before lysis and immunoblot analysis (EC+TC) (cf materials and methods). Blots were probed with antibody against actin as a loading control; immunoblot quantification is shown under each band.

Figure 2: Expression of CAMs induced by TC-EC coculture. FACS analysis of the mixed cell population (HUVEC and T24-GFP) collected from cocultures. E-selectin, ICAM-1, VCAM-1, PECAM-1, VE- and N-cadherin, $\beta 1$ and $\beta 3$ integrin were stained with phycoerythrin (PE)-conjugated antibody (red). Quantification of the CAM levels before coculture (resting HUVEC) and after 5 hours of coculture was carried out for HUVECs. The diagram shows mean fluorescence $\pm \mathrm{SD}$ of two independent experiments representative of duplicate experiments with similar results. 
Figure 3: Characterization of CAM over-expression: (a). Dose-response curves for ICAM-1 (circles), VCAM-1 (squares) and E-selectin (triangles) expression in HUVEC cocultured with 0.5 to $10.10^{5}$ T24-GFP cells. (b) Time-course of ICAM-1, VCAM-1, PECAM-1 and E-selectin expressions in endothelial cells cocultured with T24-GFP cells (EC/TC ratio of 1 ) during 1 to $6 \mathrm{~h}$. Time-course of ICAM-1 expression (c) on HUVEC stimulated with $0.5 \mathrm{U} / \mathrm{mL}$ of TNF $\alpha$ or cocultured with TCs. The fluorescence measured for resting cells (no TC added) was subtracted from each fluorescence point. The diagram shows fluorescence increase \pm SD of three independent experiments analyzed by flow cytometry. Each experiment was carried out in duplicate.

Figure 4: FACS analysis of the endothelial ICAM-1, VCAM-1, E-selectin and PECAM-1 expression after 5 hours coculture of T24-GFP and HUVECs. HUVECs monolayers were cocultured for 5 hours either in contact with T24-GFP or separated from the T24-GFP cells by $0.4 \mu \mathrm{m}$ Transwell filters. The fold increase measured for resting HUVECs was arbitrarily set to 1 . The five sketches illustrate the experimental set up. Tumor cells are represented as black circles whereas endothelial cells are in white. The dotted line shows the analyzed ECs. The diagram shows mean fluorescence \pm SD of three independent experiments. Each experiment was carried out in duplicate. Statistical significance was calculated using the Wilcoxon test (* $\mathrm{p}<0.001$ vs. resting HUVEC).

Figure 5: Analysis of the endothelial ICAM-1 expression in cocultured or in TNFastimulated HUVECs after treatment with the NFאB inhibitor (PDTC). HUVECs were treated with PDTC $(100 \mu \mathrm{M}) 1$ hour prior to experiment. Then HUVECs were either cocultured (with a ratio of $1 \mathrm{TC}$ for $1 \mathrm{EC}, 5 \mathrm{~h})$ or stimulated with TNF $\alpha(0.5 \mathrm{U} / \mathrm{mL}, 5 \mathrm{~h})$. ICAM-1 expression was analyzed by flow cytometry (cf. materials and methods). The diagram shows mean fluorescence \pm SD of three independent experiments. Each experiment 
was carried out in duplicate. Statistical significance was calculated using the Wilcoxon test (* $\mathrm{p}<0.01$ vs. without PDTC).

Figure 6: (a) Adhesion of T24 cells to HUVEC monolayer. Percentage of adherent T24 cells to either untreated or TNF $\alpha$ stimulated HUVEC monolayer $(0.5 \mathrm{U} / \mathrm{mL})$ in the presence of $20 \mu \mathrm{g} / \mathrm{mL}$ of the appropriate blocking antibody (cf. materials and methods). The percentage of adherent T24 cells compared to untreated cells (normalized to $100 \%$ ) was estimated by flow cytometry after 5 hours of TC-EC contact. (b) Transendothelial migration of T24 cells. HUVEC monolayers were either untreated or stimulated with $100 \mathrm{U} / \mathrm{mL}$ TNF $\alpha$. Then T24-GFP cells (in suspension in M199 culture medium) were added to HUVEC monolayers previously treated with the appropriate $\mathrm{mAb}(20 \mu \mathrm{g} / \mathrm{mL}$ during 30min) (cf. materials and methods). After 5 hours, the TCs that have migrated to the lower face of the filter were quantified. The diagram shows mean fluorescence \pm SD of three independent experiments. Each experiment was carried out in duplicate. Statistical significance was calculated using the Wilcoxon test $(* \mathrm{p}<0.02$ vs. control).

Figure 7: High shear stress inhibits endothelial expression of ICAM-1, VCAM-1 and Eselectin induced by coculture with $\mathrm{T} 24$ cells as well as TNF $\alpha$-induced CAMs upregulation. ECs were exposed to a shear stress of $0.9,9$ or 18 dynes $/ \mathrm{cm}^{2}$ for $24 \mathrm{~h}$ hours (HUVECs) or were presheared $19 \mathrm{~h}$ before addition of T24-GFP cells in the flow loop (coculture) or were presheared $19 \mathrm{~h}$ before the TNF $\alpha$ treatment (TNF). Shear stress was applied to ECs simultaneously with the addition of TCs or TNF $\alpha(100 \mathrm{U} / \mathrm{mL}$ ) for $5 \mathrm{~h}$ (see materials and methods). Quantification of the ICAM-1 (a), VCAM-1 (b) and E-selectin (c) levels were carried out for endothelial cells by flow cytometry. (d) In additional experiments ECs were exposed to 9 dynes $/ \mathrm{cm}^{2}$ for $24 \mathrm{~h}$ (HUVECs), or presheared for $19 \mathrm{~h}$ before $5 \mathrm{~h}$ coculture at 9 dynes $/ \mathrm{cm}^{2}$ (Coculture), or presheared for $18 \mathrm{~h}$ at 9 dynes $/ \mathrm{cm}^{2}$, then treated with 
PDTC $(100 \mu \mathrm{M})$ for $1 \mathrm{~h}$ under flow prior to $5 \mathrm{~h}$-coculture at 9 dynes $/ \mathrm{cm}^{2}$ (PDTC + Coculture). The diagram shows mean fluorescence \pm SD of two independent experiments at least. Immunoblots for ICAM-1 (e) and I $\mathrm{I} B \alpha$ (f) expression before and after coculture are also presented. Samples were taken from resting HUVECs (EC) and TNF $\alpha$ stimulated HUVECs (TNF) $100 \mathrm{U} / \mathrm{mL}$ for $30 \mathrm{~min}$ (f) or $24 \mathrm{~h}(\mathrm{e})$. ECs were presheared $19 \mathrm{~h}$ at 9 dynes $/ \mathrm{cm}^{2}$ before coculture with TCs at the same flow $\left(\right.$ Co 9 dynes $\left./ \mathrm{cm}^{2}\right)$ for $30 \mathrm{~min}$ (f) or $5 \mathrm{~h}$ (e). Same experiments were prepared for coculture under 18 dynes $/ \mathrm{cm}^{2}$ shear stress $\left(\right.$ Co $\left.18 \mathrm{dynes} / \mathrm{cm}^{2}\right)$. ECs were also presheared $18 \mathrm{~h}$ at 9 dynes $/ \mathrm{cm}^{2}$ then treated with PDTC $(100 \mu \mathrm{M})$ for $1 \mathrm{~h}$ under flow prior to $5 \mathrm{~h}$-coculture at 9 dynes $/ \mathrm{cm}^{2}$ (Co 9 dynes $/ \mathrm{cm}^{2}+$ PDTC) for $5 \mathrm{~h}$ (e) or $30 \mathrm{~min}$ (f). In (f) TC-EC were cocultured for 30min under static condition (Co static). T24 cells and ECs were also cultured separately then mixed together (with a ratio of 1 TC for 2 ECs) before lysis and immunoblot analysis (EC+TC) (control of ICAM-1 level without coculture, as described in material and methods). Blots were also probed with antibody against actin as a loading control; immunoblot quantification is shown under each band. Statistical significance was calculated using the Wilcoxon test $(* \mathrm{p}<0.001$ vs. presheared HUVEC control at the same shear stress; \# $\mathrm{p}<0.03$ vs. 0.9 dynes $/ \mathrm{cm}^{2}$ presheared HUVEC control at $\left.0.9 \mathrm{dynes} / \mathrm{cm}^{2}\right)$.

Table 1: FACS analysis of the endothelial ICAM-1 expression after 5 hour-contact between a carcinoma cell line and HUVECs. HUVEC monolayers were cocultured for 5 hours in contact with, DAG-1, T24 or TCCSUP cells (bladder carcinoma), MCF7 or MDA cells (breast adenocarcinoma), Calu-6 or A549 cells (lung carcinoma) and RKO cells (colon adenocarcinoma) stained with $20 \mu \mathrm{M}$ of Cell Tracker Green. Quantification of the ICAM-1 level was carried out for endothelial cells by flow cytometry. Fold increase was calculated as the ratio of endothelial ICAM-1 after coculture on ICAM-1 expression on resting HUVECs. 


\section{Titles and legends to figures for supplementary data}

Figure S1: Tumor cell expression of CAMs induced by TC-EC coculture. FACS analysis of the mixed cell (HUVEC and T24) collected from cocultures. ICAM-1, N-cadherin, $\beta 1$ and $\beta 3$ integrin were stained with phycoerythrin (PE)-conjugated antibody (red). Quantification of the CAM levels before coculture (resting TC) and after 5 hours of coculture was carried out for T24 cells. The diagram shows mean fluorescence \pm SD of two independent experiments in duplicate.

Figure S2: CAMs over-expression kinetics. Dose-response curves for ICAM-1 expression in HUVEC cocultured with various concentrations of TNF $\alpha$, from 0.2 to $200 \mathrm{U} / \mathrm{mL}$ (a). Timecourse of E-selectin (b), and VCAM-1 expression (c) on HUVEC stimulated with $0.5 \mathrm{U} / \mathrm{mL}$ of TNF $\alpha$ or cocultured with TCs. The fluorescence measured for resting HUVECs (time 0h) was subtracted from each fluorescence point. The diagrams show mean fluorescence \pm SD of three independent experiments analyzed by flow cytometry. Each experiment was carried out in duplicate.

Figure S3: Effect of shear flow on the number of attached TCs. Percentage of attached TCs on the EC monolayer (relative to the number of TCs remaining on the EC monolayer at the end of the 15-min incubation time).

Figure S4: FACS analysis of endothelial ICAM-1 expression after 24 hours coculture of T24-GFP and HUVECs. HUVECs monolayers were cocultured for 24 hours either in contact with T24-GFP or separated from the T24-GFP cells by $0.4 \mu \mathrm{m}$ Transwell filters. The four sketches illustrate the experimental set up. Tumor cells are represented as black circles whereas endothelial cells are in white. The dotted line shows the analyzed ECs. The diagram shows mean fluorescence \pm SD of two independent experiments. Each experiment was carried 
out in duplicate. Statistical significance was calculated using the Wilcoxon test $(* \mathrm{p}<0.01$ vs. resting HUVEC).

Figure S5: Effect of TC conditioned medium on the endothelial ICAM-1 expression. HUVECs were either cocultured (with a ratio of 1 TC for 1 EC for $5 \mathrm{~h}$, "Coculture") or incubated $5 \mathrm{~h}$ with a $5 \mathrm{~h}$-TC-EC coculture conditioned medium (HUVEC + coculture medium), or incubated $5 \mathrm{~h}$ with a $5 \mathrm{~h}$-TC conditioned medium (HUVEC + T24 medium). ICAM-1 expression was analyzed by flow cytometry (cf. "materials and methods"). The diagram shows mean fluorescence \pm SD of three independent experiments. Each experiment was carried out in duplicate. Statistical significance was calculated using the Wilcoxon test (* $\mathrm{p}<0.01$ vs. resting HUVEC). 


\section{Tables}

\section{Table 1}

\begin{tabular}{|c|c|}
\hline Cell lines & $\begin{array}{c}\text { EC ICAM-1 fold increase } \\
\text { induced by coculture }\end{array}$ \\
\hline DAG-1 & $0,8 \pm 0,1$ \\
\hline T24 & $\mathbf{4 , 2} \pm \mathbf{0 , 1}$ \\
\hline TCCSUP & $1,1 \pm 0,1$ \\
\hline MCF7 & $0,9 \pm 0,1$ \\
\hline MDA & $\mathbf{4 , 1} \pm \mathbf{0 , 3}$ \\
\hline Calu-6 & $0,9 \pm 0,1$ \\
\hline A549 & $1,0 \pm 0,2$ \\
\hline RKO & $0,8 \pm 0,1$ \\
\hline
\end{tabular}


Figures

Figure 1
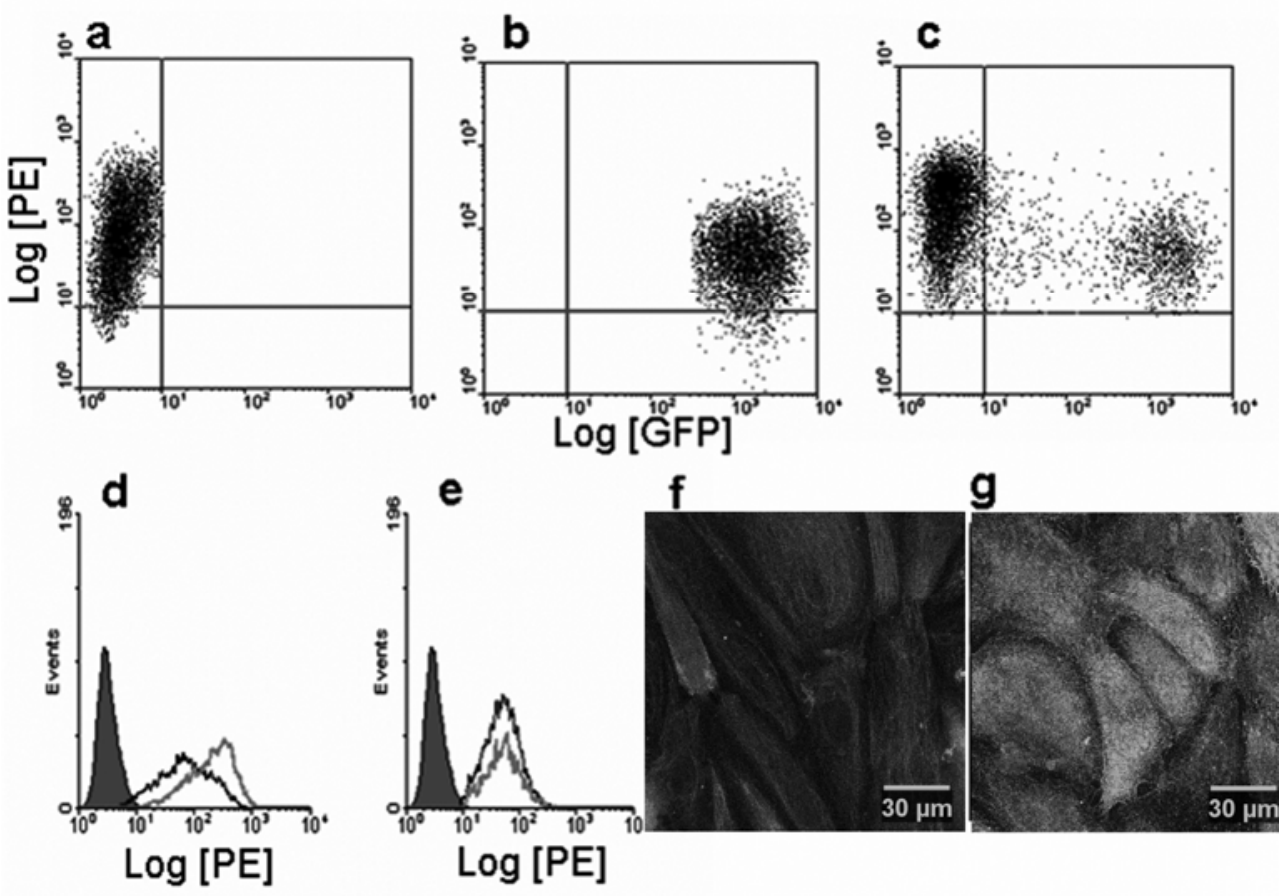

h

EC TC Co EC+TC
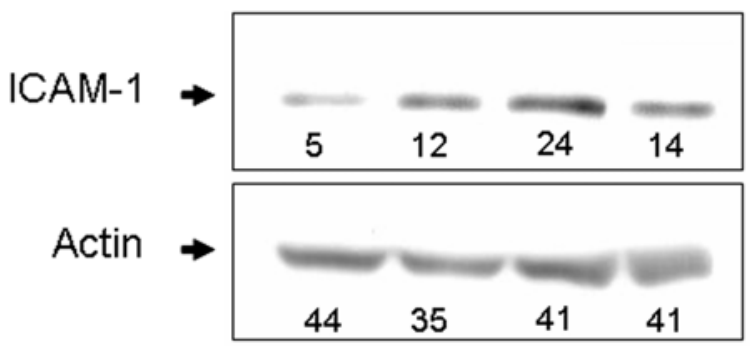
Figure 2

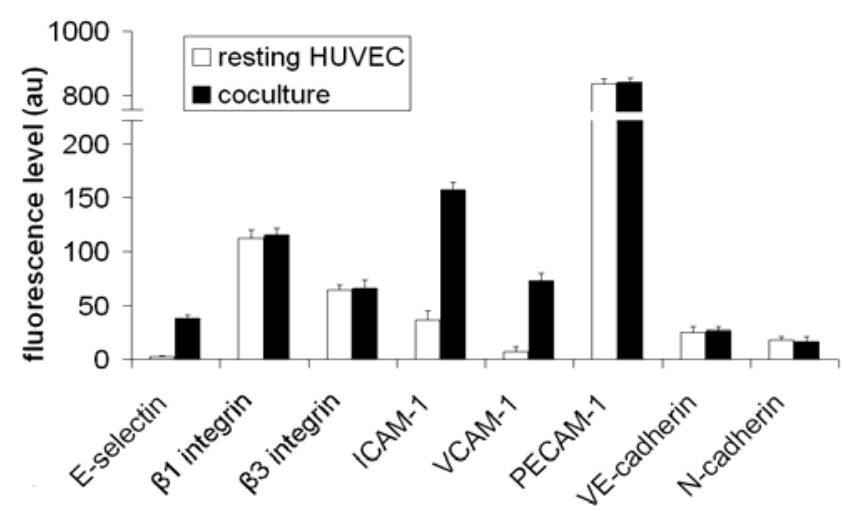




\section{Figure 3}
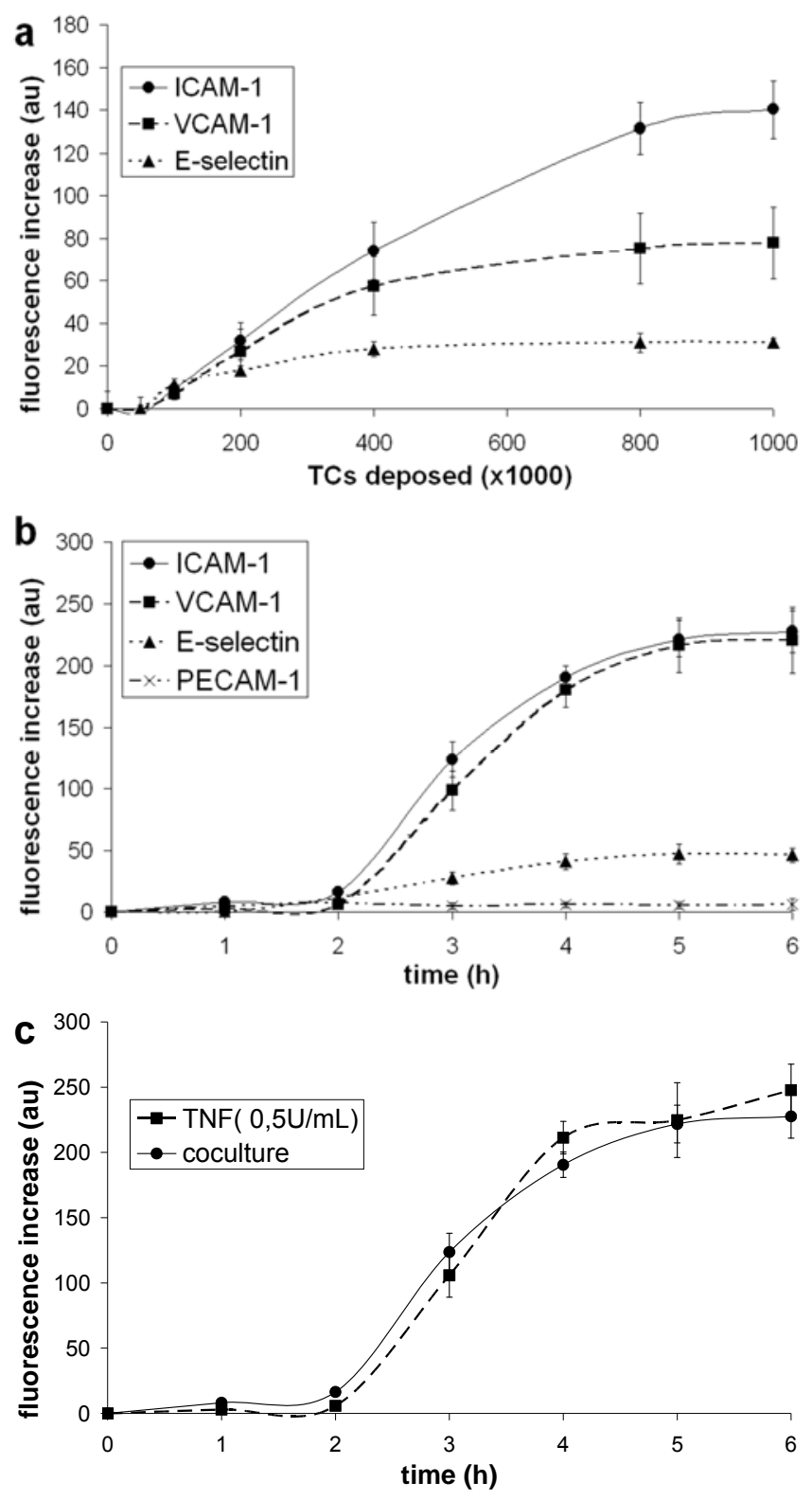


\section{Figure 4}

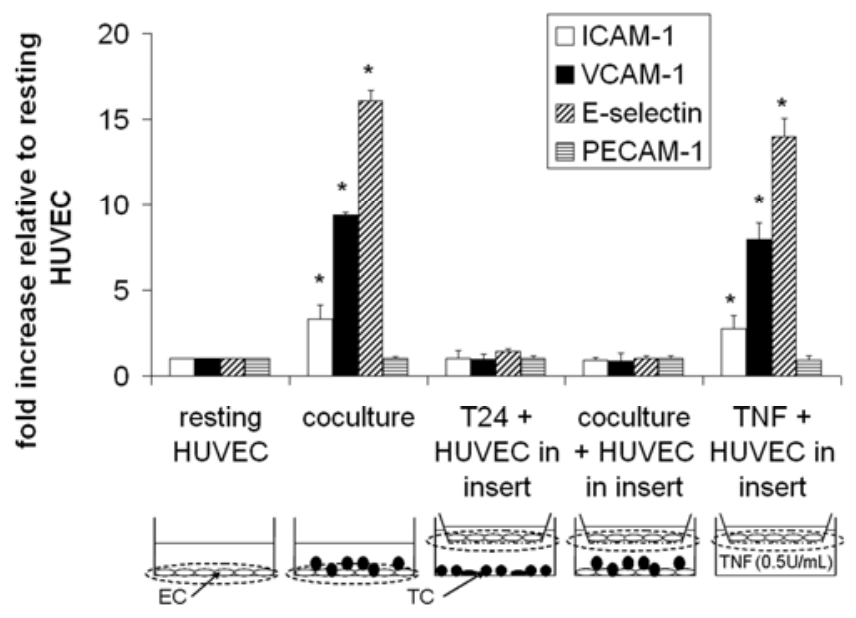


Figure 5

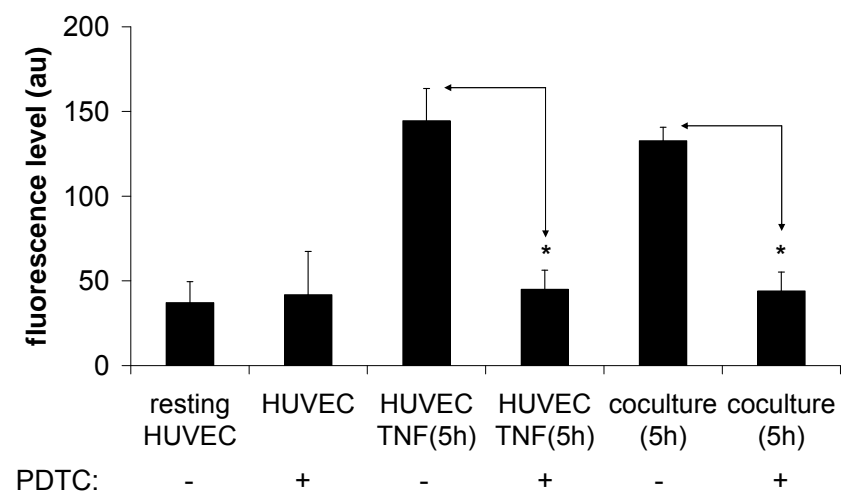




\section{Figure 6}
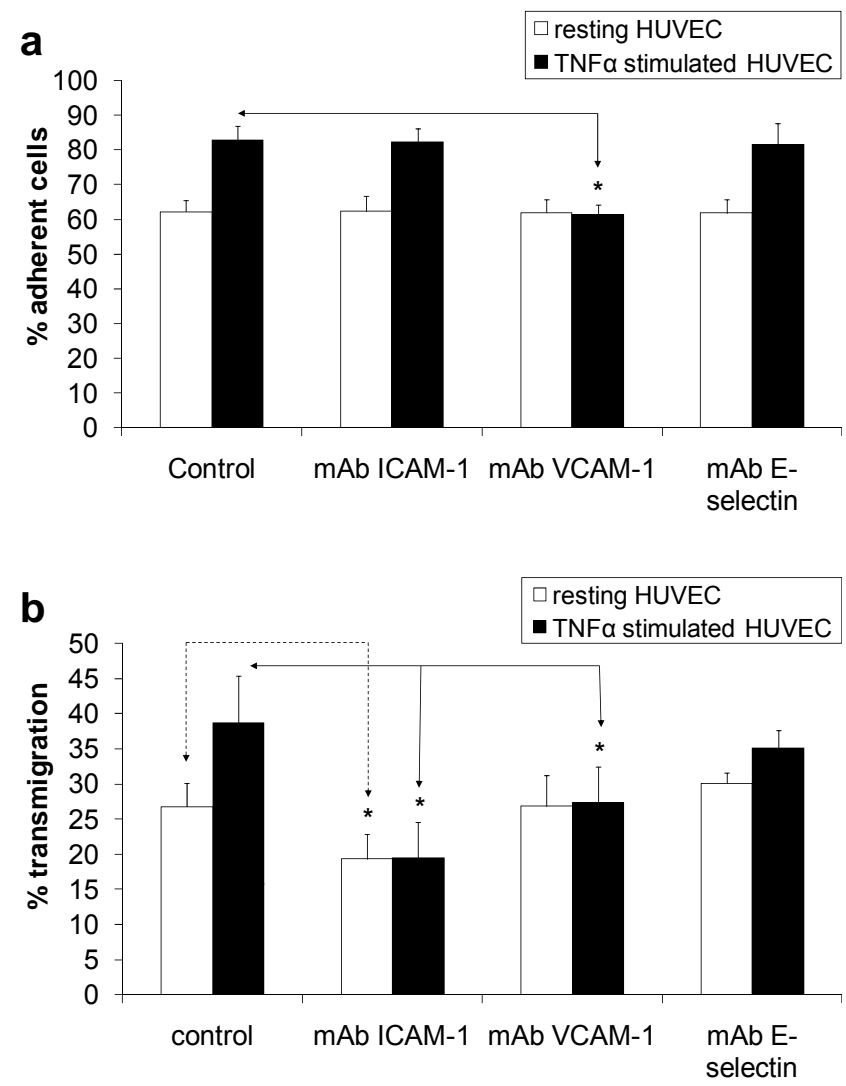


\section{Figure 7}

a

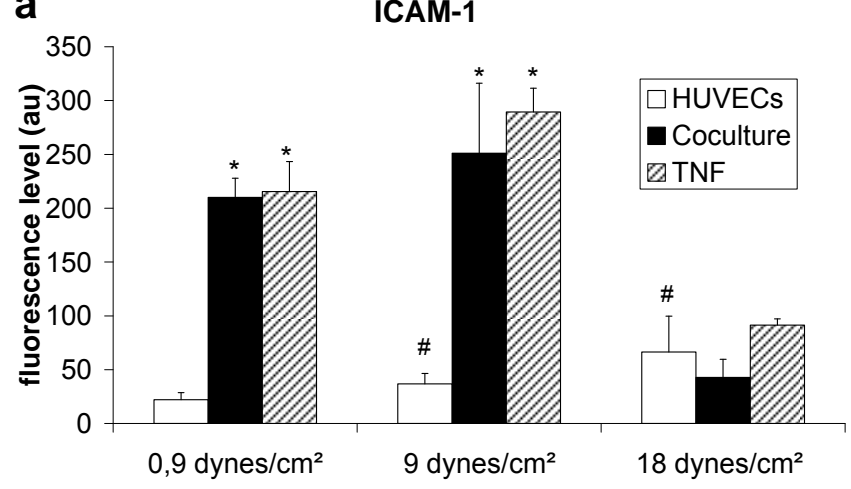

b VCAM-1

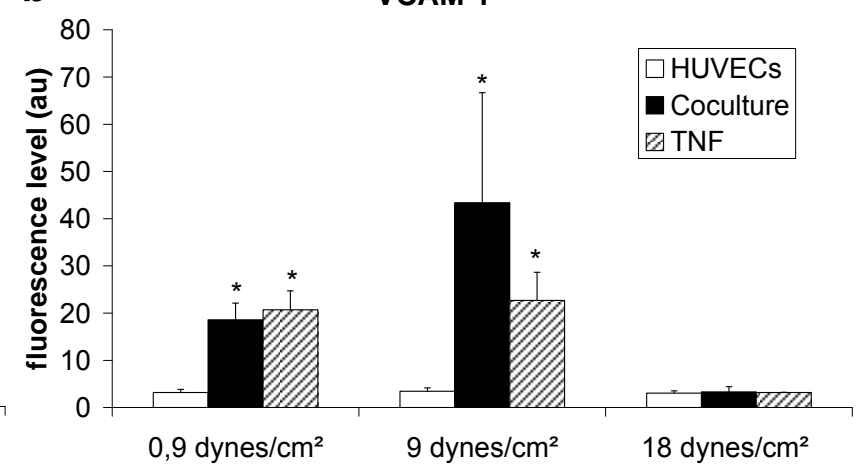

d

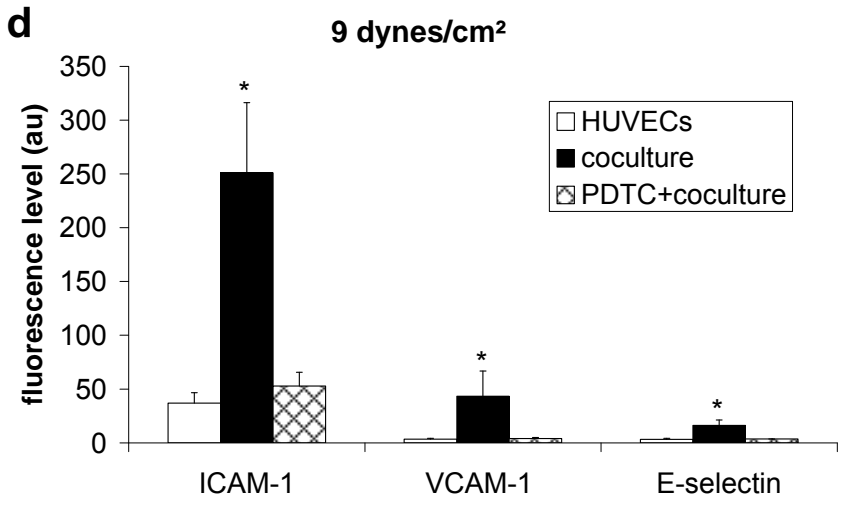

9 dynes $/ \mathrm{cm}^{2}$

f
C

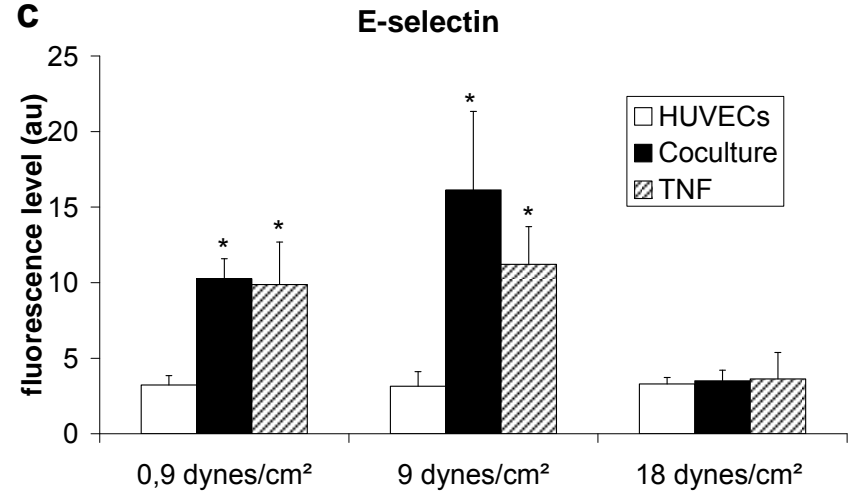

e

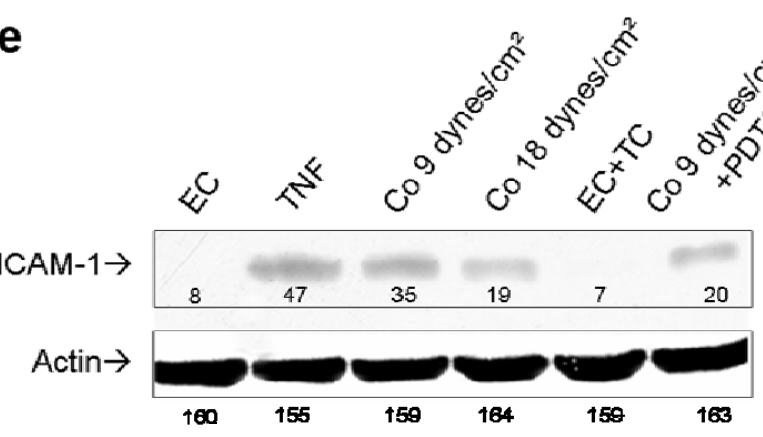

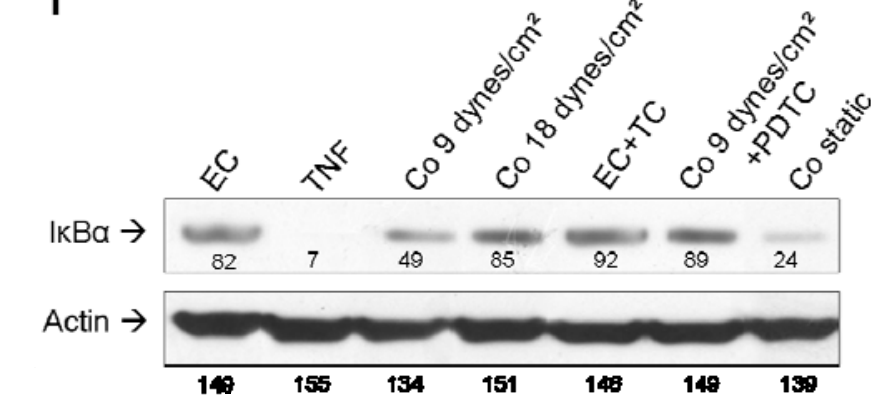




\section{Supplementary data}

S1

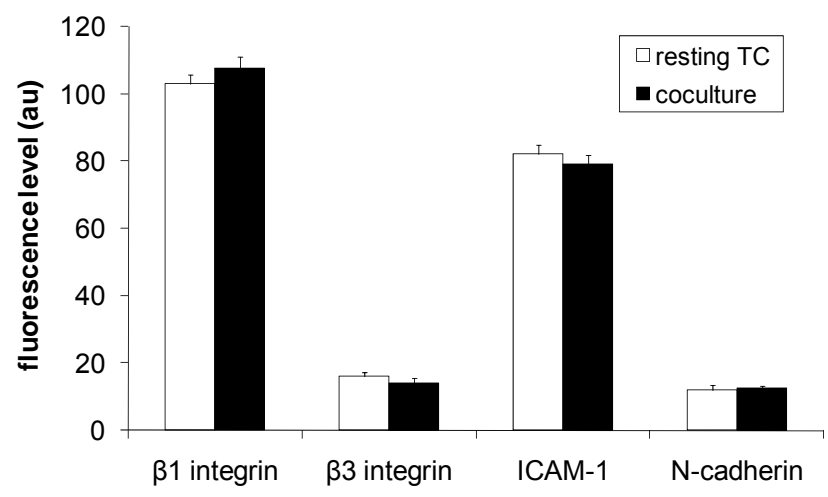


S2

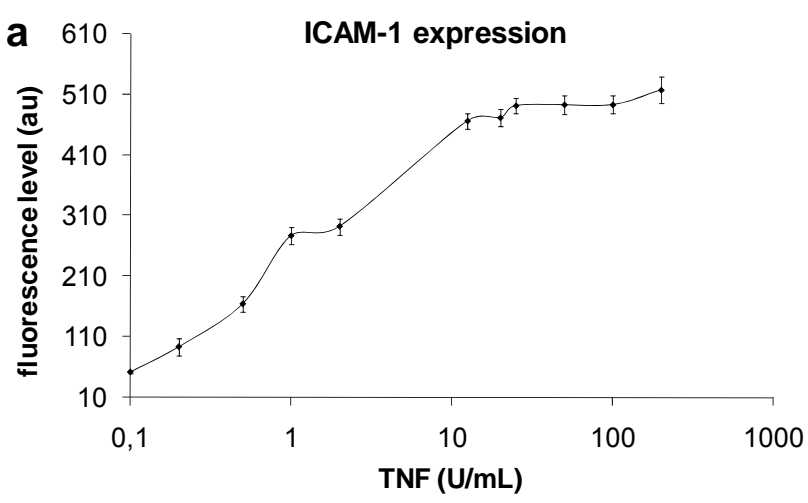

b E-selectin overexpression kinetics

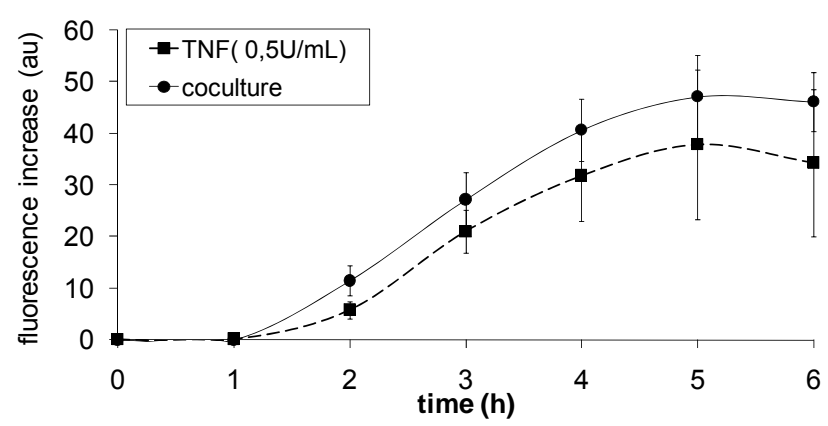

C VCAM-1 overexpression kinetics

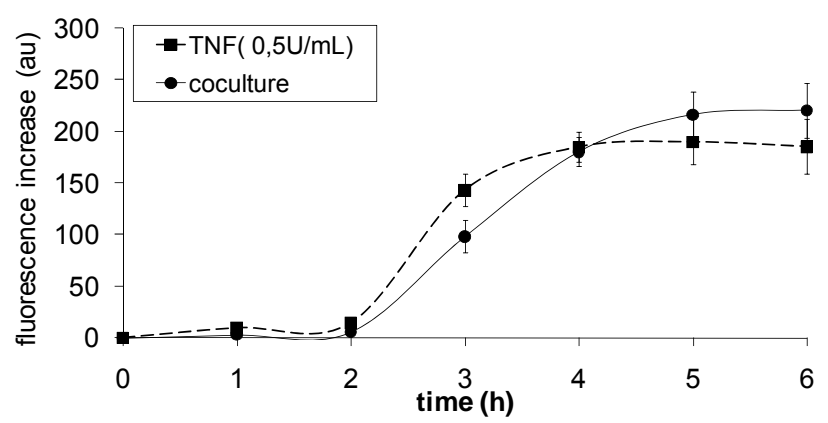


S3

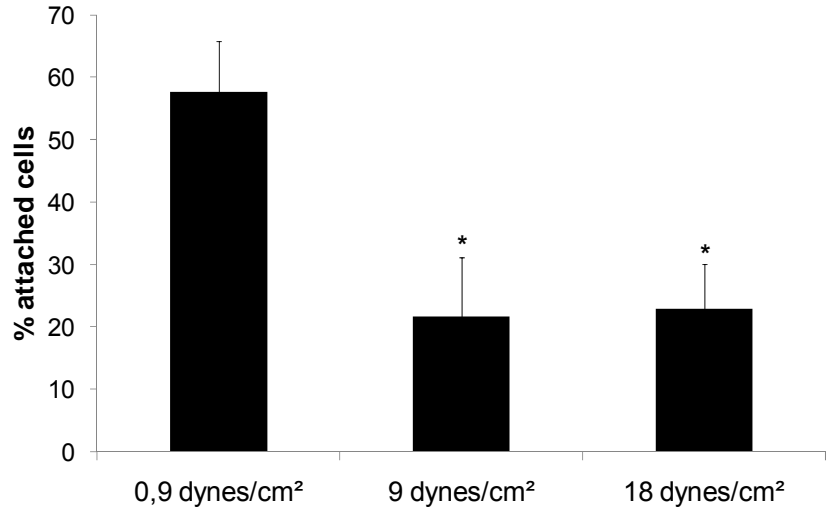




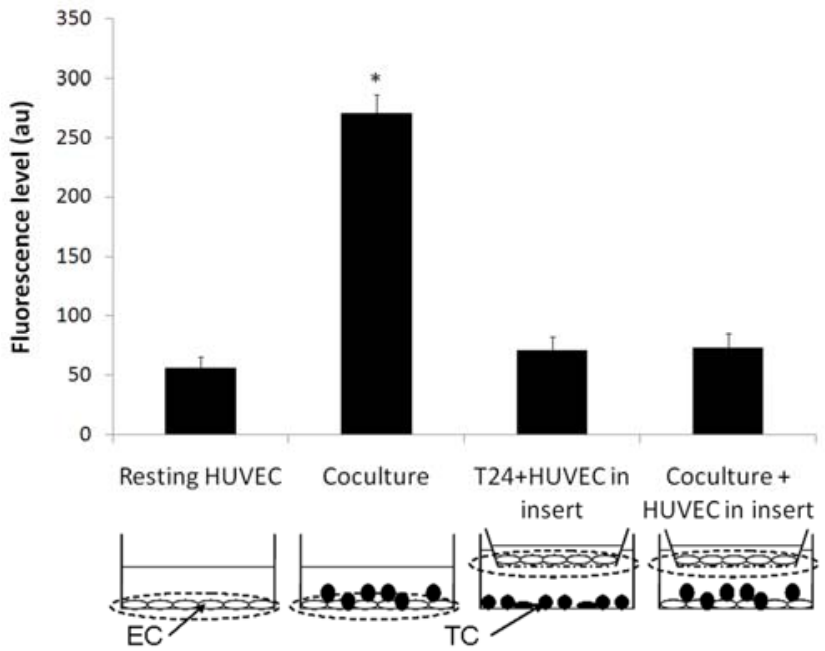




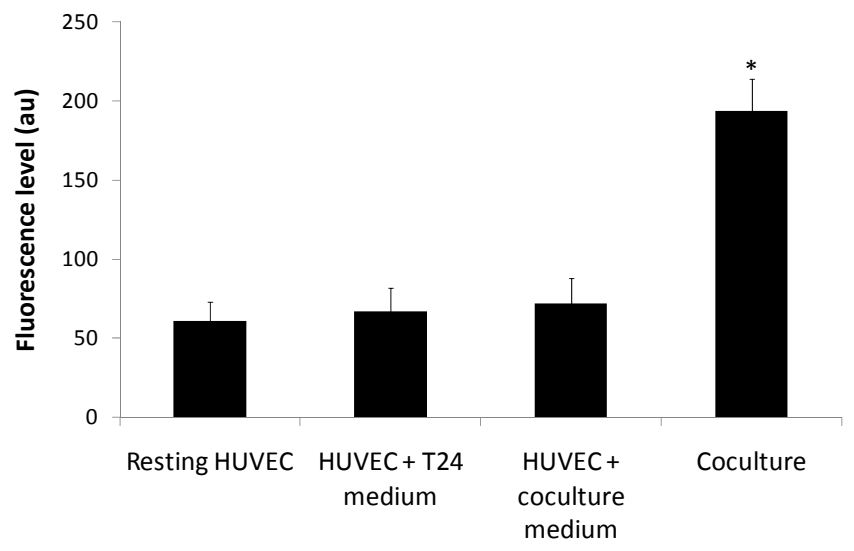

